\title{
Payments for ecosystem services within the hybrid governance model: evaluating policy alignment and complementarity on California rangelands
}

\author{
Nicole Buckley Biggs ${ }^{1}$, Jayce Hafner ${ }^{1}$, Fadzayi E. Mashiri $^{2}$, Lynn Huntsinger $^{3}{ }^{\text {and Eric F. Lambin }}{ }^{1,4,5}$
}

\begin{abstract}
Governance of global natural resources is increasingly hybrid, with complementary public and private sector initiatives layered on landscapes to improve environmental outcomes. The challenge of polycentric land use governance is alignment of goals across diverse governance mechanisms when agricultural producers, public agencies, and corporations have distinct motivations. This case study of soil carbon governance on California rangelands explores a new payment for ecosystem services (PES) initiative led by the food and agriculture industry, called the Ecosystem Services Market Consortium (ESMC). Applying hybrid governance theory to agricultural lands, we conduct an ex-ante policy evaluation of potential policy impact based on (i) alignment between corporate sustainability goals and ranchers' priorities and (ii) complementarity of the ESMC market with existing public and private policies enabling rangeland conservation. We found corporations developing the PES market to be motivated by carbon insetting, the objectives of which converge with ranchers' goals of preserving soils. Each policy offers distinct benefits and challenges, with synergies around climate change adaptation and soil health. As a new policy tool, carbon markets like the ESMC are positioned to meet demand for soil health financing, support resilience and ranch productivity, and improve ranchers' access to soil health data for adaptive management. Given carbon markets' outcome-based payment structure, we highlight the importance of complementary governance mechanisms that mitigate upfront risk with financial and technical support during the transition period, including Farm Bill cost-share programs and private sector financing tools. This policy evaluation highlights the challenges and opportunities surrounding rangelands soil carbon governance, particularly the trade-offs that ranchers, corporations, and society at large must consider for landscape-scale conservation programs.
\end{abstract}

Key Words: carbon markets; carbon insetting; climate adaptation; environmental governance; payments for ecosystem services; rangelands management

\section{INTRODUCTION}

The multiscalar nature of global environmental issues requires multilevel environmental governance (Lemos and Agrawal 2006), as layered policies working at local to international scales interact to influence management outcomes through both command-andcontrol and incentives-based approaches (Lambin and Meyfroidt 2010, Ostrom and Cox 2010). Environmental governance is defined as the "set of regulatory processes, mechanisms and organizations through which political actors influence environmental actions and outcomes" (Lemos and Agrawal 2006:298). These processes extend beyond government to include corporations, nongovernmental organizations (NGOs), and communities. When it comes to hybrid governance, public and private sector policies can reinforce each other if there are shared goals across actors, even when these actors have distinct motivations. In fact, multiple environmental policies can interact in complementary and beneficial ways, where a confluence of policy organizations often produces better environmental outcomes than few or single governance bodies (Nagendra and Ostrom 2012).

We present a case study of hybrid environmental governance as applied to California rangelands. We conduct an ex-ante policy evaluation of the potential impact of a new payments for ecosystem services (PES) initiative led by the food and agriculture industry, called the Ecosystem Services Market Consortium (ESMC), on California cattle ranches. Amidst the array of rangeland natural resources (Spiegal et al. 2016, Sala et al. 2017), we examine soil organic carbon (or "soil carbon," for the purposes of this paper) in particular, because of both the growing interest in carbon sequestration on agricultural lands as a climate change mitigation strategy and the vast scale of global rangelands, which hold an estimated one-third of global soil carbon (Follett and Reed 2010, Delonge et al. 2014).

Lively debate continues around the value of hybrid approaches to natural resources governance, perhaps most apparent in studies relating to climate change mitigation (Jordan et al. 2015). Since the 1970s, the global environmental governance paradigm has shifted away from a centralized government control model engaging panacea-type solutions (Ostrom and Cox 2010) toward more decentralized, cross-sector governance. Under this new approach to social-ecological systems governance, both community-based natural resources management and marketbased instruments have grown in popularity (Lemos and Agrawal 2006). This decentralized approach to sustainable resource management takes advantage of the diverse benefits of - and complementarity between-governance tools (Lambin et al. 2014) and ideally is flexible to local resource contexts (Ostrom and Cox 2010).

California rangelands provide a strong case study for hybrid governance. California is a top-5 beef producing state (NASS 2018) with over a third of its land area grazed by livestock (FRAP 2017). The state runs a cap and trade program created by the 2006 California Global Warming Solutions Act (AB 32), the proceeds

\footnotetext{
${ }^{1}$ School of Earth, Energy, and Environmental Sciences, Stanford University, Stanford, CA, USA, ${ }^{2}$ University of California Cooperative Extension, ${ }^{3}$ University of California, Berkeley, USA, ${ }^{4}$ Woods Institute for the Environment, Stanford University, Stanford, CA, USA, ${ }^{5}$ Georges Lemaitre Earth and Climate Research Centre, Earth and Life Institute, Université Catholique de Louvain, Belgium
} 
of which fund the California Healthy Soils Program (HSP). California is also home to a proliferation of private-sector initiatives focused on soil carbon and regenerative farming. Although the diverse agencies and layers of governance in California can be frustrating for ranchers when policies overlap or work against each other (American Farmland Trust 2012), potential synergies among layered policies deserve closer examination.

To improve understandings of hybrid governance of rangeland soils, this study investigates the ESMC, a novel PES policy likely to become available to California farmers and ranchers over the next few years. Based on the existing hybrid governance literature (Lemos and Agrawal 2006, Börner and Vosti 2013, Lambin et al. 2014), we identify two criteria that indicate the likely success of this policy in contributing to climate change mitigation, adaptation, and soil health: policy alignment and complementarity. Regarding alignment, policy makers' goals may diverge from the goals of the policy's target participants, yet some alignment is generally required for policy traction, especially for voluntary initiatives. The second criterion, complementarity, refers to how well a new policy fits within existing policies. A new program that addresses the gaps or barriers to participation of existing policies is more likely to have long-term success and impact. We explore these criteria by evaluating (i) policy alignment between corporate sustainability goals and ranchers' soil conservation priorities and (ii) complementarity of the ESMC market as it intersects with existing public and private conservation policies.

This ex-ante approach to policy evaluation informs the development of new conservation policies and increases the chances of their long-term success, in contrast to more traditional ex-post evaluations often conducted years after policy failure or success. Various frameworks for evaluating the effectiveness of PES policies have emerged over the past two decades (Engel et al. 2008, Corbera et al. 2009, Vatn 2010, Primmer et al. 2013), including recent ex-ante policy studies engaging interviews, surveys, media coverage, and other documentation to evaluate the likely socio-political and environmental outcomes of PES (Chinangwa et al. 2017, Tikkanen et al. 2017). Other ex-ante PES evaluations have used experiments to evaluate how policy design can impact producer decision making (Chinangwa et al. 2017, Hermann et al. 2017) and environmental outcomes (Sarwosri et al. 2018). Our research contributes empirical evidence for how agricultural producers perceive and engage with multiscale governance mechanisms (Dauvergne and Alger 2018) to achieve their own landscape-level goals, as well as the policy interactions playing out on rangelands today. These findings have relevance beyond California, including for environmental governance experts; those who design public and private conservation programs for working lands; beef producers and consumers; and philanthropists and investors.

\section{BACKGROUND}

Ecosystem services are the elements of nature used by humans to support human well-being (Westman 1977, Daily 1997, Nahlik et al. 2012). This concept proves useful when applied to agriculture because of the many benefits derived from agricultural lands beyond crop and meat production, including wildlife habitat, water services, carbon storage, and open space for recreation. The variety of ecosystem services provided by working lands, whether croplands, pasture, or rangelands, can be supported through multiple government and private sector-led approaches. Land use governance tools pertinent to agricultural lands include ecocertifications and price premiums, PES, and government grant and cost-share programs, each approach offering distinct benefits (Lambin et al. 2014; see Fig. 1).

\section{Government-led sustainable land use incentives}

Government-financed rangeland conservation programs include cost-share programs, tax reductions, subsidies, and conservation easements, generally voluntary and funded by state or federal agencies. As the largest private land conservation organization in the U.S., the USDA Natural Resources Conservation Service (NRCS) administers Farm Bill programs that support fencing and water infrastructure development, which can improve grazing management and reduce soil erosion. These programs include the Environmental Quality Incentives Program (EQIP), the Conservation Stewardship Program (CSP), the Grassland Reserve Program (GRP), and the Agricultural Conservation Easement Program (ACEP).

Many government cost-share programs support soil health in particular, or "the capacity of soil to function as a vital living system, within ecosystem and land-use boundaries, to sustain plant and animal productivity, maintain or enhance water and air quality, and promote plant and animal health" (Doran and Zeiss 2000:3). Improving soil health includes reducing disturbance, maximizing soil cover, supporting biodiversity, and ensuring the presence of living roots (NRCS 2017). Government programs also provide financial assistance to support water quality and wildlife (Huntsinger et al. 2010), including wildlife-friendly fencing and off-stream water development projects (Mannix and Allison 2018).

Government agencies also fund conservation easements, a land use agreement in which a landowner transfers the development rights of his or her property to a land trust or public agency. Conservation easements can indirectly support soil health by providing funding for on-ranch improvements and by preventing erosion associated with conversion to development (Diaz et al. 2012). In the U.S., these easements are most often implemented in partnership with NGOs like the American Farmland Trust, The Nature Conservancy, and the California Rangeland Trust (Cheatum et al. 2011, Booker et al. 2013, Huntsinger and Bartolome 2014).

At the state level, California invests significantly in natural resources conservation. The state's voters have approved seven natural resources bonds since Proposition 12 two decades ago (LAO 2017), now totaling over $\$ 30$ billion in bond funds to protect and restore open space and working lands (CARB 2019). The California Natural Resources Agency invests in conservation easements through its Sustainable Agricultural Lands Conservation (SALC) Program (CARB 2019). The state has also been innovative in its use of payments to incentivize conservation activities on rangelands, including the California Department of Food and Agriculture HSP Incentives Program that invests in carbon sequestration on working lands. For the year 2020 alone, HSP invested over $\$ 22$ million in 316 projects, funded mostly by state cap and trade proceeds (CDFA 2020). 
Fig. 1. Public and private sector policies supporting sustainability on rangelands. Source: Based on payments for ecosystem services categories developed by Forest Trends \& Ecosystem Services Marketplace (2008), Goldstein et al. (2011), and Salzman et al. (2018).

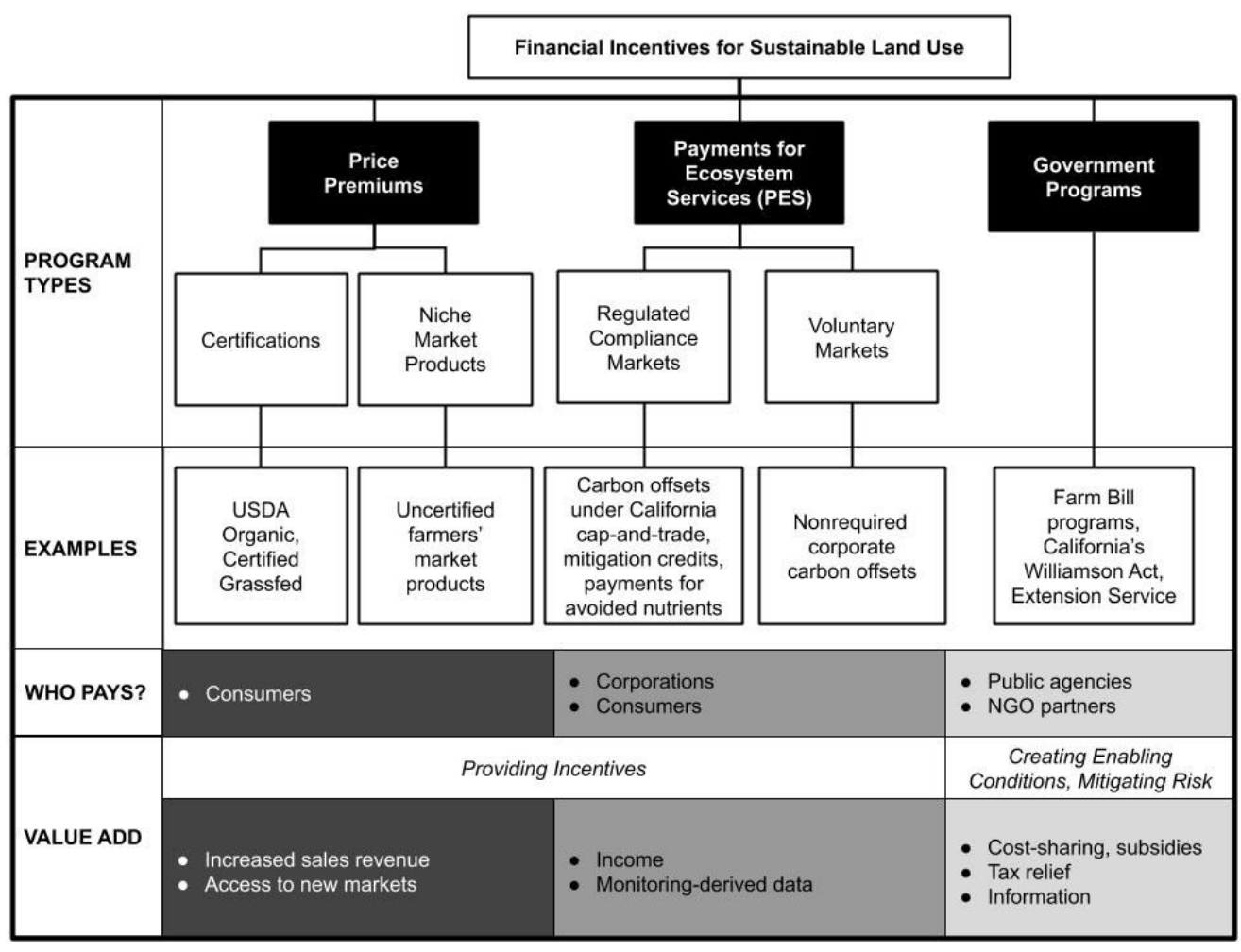

\section{Eco-certifications and price premiums}

Eco-certification programs provide producers with additional income for value-added, niche products with improved quality or sustainability relative to existing commodities. Certification programs can be government-led or initiated by NGOs. Currently available beef-related sustainability certifications include grassfed (e.g., A Greener World's Certified Grassfed, PCO Grassfed Certified, American Grassfed Association Certification, and USDA Grass Fed programs), regenerative, USDA Organic, wildlife-friendly (e.g., Audubon Certified Grazed on BirdFriendly Land), and natural certifications.

There are diverse incentives for cattle ranchers to market niche products in exchange for price premiums (Crowley et al. 2019), including increased income potential, price stability, and educational opportunities that can bolster production, cut costs, integrate new technologies, or increase production efficiency (Hajjar et al. 2019). Yet the drawbacks of niche market products are significant, particularly the onerous, costly, and slow certification processes. The length and multifaceted nature of the beef value chain make standardization challenging to monitor and quantify, e.g., compared with coffee certification (Mora 2018, Hajjar et al. 2019). A proliferation of sustainability-related labels confuse both producers and consumers (Barnette et al. 2016, Buckley et al.2019) and it is often unclear whether price premiums reach producers (Blomquist et al. 2015, Naegele 2019). Finally, grass-finishing cattle can be challenging on California rangelands because of the climate and seasonal variations in forage availability, with ranchers often citing meat quality and lack of infrastructure as barriers to grass-finishing (Gwin 2009). Given the limitations of price premium incentives, many producers opt out of sustainability certifications altogether.

\section{PES market incentives}

A final category of PES is formal markets, worth an estimated $\$ 36 \mathrm{~B}$ globally. These markets allow for financial transactions that are an "exchange of value for land management practices intended to ensure or provide ecosystem services" (Salzman et al. 2018:136). Formal PES markets include both compliance-driven and voluntary markets. For example, companies report carbon emissions and trade carbon offset credits through PES markets, covering emissions from sources directly operated or owned by the reporting company (Scope 1); electricity, heat, or steam purchased by the reporting company (Scope 2); or from the entire value chain of a product (Scope 3; WRI and WBCSD 2014).

To meet the demand for voluntary and compliance carbon offsets and growing interest in agricultural carbon, various markets and protocols have been developed for soil carbon sequestration in agricultural landscapes. These include the U.S.'s Chicago Climate Exchange (CCX), Australia's Emission Reduction Fund (ERF), protocols used by Verra's Verified Carbon Standard (CAR 2019), and the American Carbon Registry's Avoided Conversion of Grasslands and Shrublands to Crop Production (ACoGS) methodology. The U.S. does not have a national cap and trade program for GHG emissions, although GHG regulations have 
been passed at the state level, such as California's AB 32 and SB 32. Until its closure in 2010, the CCX served as a voluntary GHG emissions cap and trade scheme for North America, with rangelands carbon integrated into the market (Goldstein et al. 2011). CCX included an estimated 1000 ranchers based mostly in the Great Plains (Gosnell et al. 2011). Lessons from the CCX led to a shift from focusing on specific practices for sequestering carbon to actual project-level outcomes, i.e., a shift from "rulesbased" to "outcome-based" compensation for soil carbon (Gosnell et al. 2011). New tools and initiatives have since proliferated to establish a balance between the rigor of carbon monitoring and the scalability of a market. These include planning tools like COMET-Farm and initiatives like the Montana Grasslands Carbon Program, Wyoming Carbon Credit Initiative, Terra Global Capital, and the Ecosystem Services Market Consortium.

PES programs offer ranchers the opportunity to mitigate risk by diversifying and improving income (Toombs et al. 2011), yet these opportunities also come with significant challenges. Compensating landowners for soil carbon through PES markets generally depends on additionality, with the exception of programs that compensate landowners for existing soil carbon or avoided grassland conversion. For markets that require measurable augmentation of soil carbon, additionality can be difficult to ensure on semiarid and arid rangelands because of their nonequilibrium nature (Westoby et al. 1989, Vetter 2005, Booker et al. 2013), with variable outcomes depending on local edaphic and climatic characteristics (Carey et al. 2020). California's rangelands are notable in their heterogeneity and spatial variability, ranging from arid inland valleys to mesic grasslands along the coast (Vetter 2005, Huntsinger and Bartolome 2014, Sloat et al. 2018). On most California rangelands, abiotic variables like precipitation play a stronger role in productivity than biotic factors (Oba et al. 2000, Engler and von Wehrden 2018, di Virgilio et al. 2019). Soil carbon sequestration resulting from management changes varies significantly across regions based on soil moisture (Soussanna et al. 2004), largely due to differences in net primary productivity and residue breakdown (Follett and Reed 2010). As a result, adoption of specific management practices by ranchers on California's arid and semiarid rangelands does not reliably impact carbon cycling (Booker et al. 2013, Briske et al. 2014). Outcomes are further tempered by site-specific plant communities because grasses utilizing a $\mathrm{C} 4$ photosynthetic pathway can support soil carbon augmentation but vary in regional presence (McSherry and Ritchie 2013, Abdalla et al. 2018).

Historical stewardship efforts by landowners can also influence additionality, particularly where soils are saturated at maximum carbon stabilization capacity (Gosnell et al. 2011, Booker et al. 2013). This can reduce the ability of additionality-based markets to reward changes in soil management. Another technical challenge to soil PES initiatives is the permanence of newly stored carbon, particularly at the project or operational level (Conte et al. 2011, Bossio et al. 2020). For carbon credits to be considered as offsetting GHG emissions, they must be both additional to the baseline scenario and permanent (Thamo and Pannell 2016). Recent studies have challenged the validity of assumed baseline scenarios under business as usual because the estimated soil carbon sequestered or GHG emissions produced in the absence of the offset may be inaccurate (Haya et al. 2020).
Finally, in a classic "precision vs. practicality" dilemma, the CCX showed that the more data-driven the protocol, the less likely ranchers are to participate in a carbon market (Gosnell et al. 2011). On the other hand, less rigorous protocols have been found to be uncompetitive on carbon credit markets, and many ranchers have found payments for soil carbon to be inadequate for offsetting enrollment or implementation costs (Hansen et al. 2018). Transitioning to new practices can be challenging, sometimes taking a decade to complete, as in the case of transitioning to rotational grazing systems (Gosnell et al. 2011). These challenges were echoed by California ranchers surveyed by Cheatum et al. (2011), who expressed dissatisfaction with PES programs and the bureaucratic hurdles associated with participation.

Cultural, economic, and political barriers are also present in carbon sequestration on rangelands (Follett and Reed 2010). A range of factors prevent ranchers from participating in conservation programs or adopting new management practices, including characteristics like social networks, education, values and culture (Chan et al. 2012, Lubell et al. 2013, Brain et al. 2014, Roche 2016), ranch system dynamics (Sayre 2004, Wilmer and Fernández-Giménez 2015), the type of public or private organization managing a program (Cheatum et al. 2011), program design (Didier and Brunson 2004, Farley et al. 2017), landowners' production goals (Peterson and Coppock 2001, Lubell et al. 2013), as well as agency staff turnover and paperwork burden (Aoyama and Huntsinger 2019). Research is needed to understand these barriers to implementing PES markets on rangelands, matching the current level of investment in soil carbon measuring and monitoring technologies. This should include better understanding how to frame program engagement in a way that is meaningful for ranchers and their daily experiences on the land. Cheatum et al. (2011) found ranchers to be highly sensitive to the policy administrator, with lower payments expected from preferred administrators (identified as nonprofits and private companies over government administrators, with state agencies being the least preferred). This personal preference factor often determines the difference between what is physically possible and what is socially achievable (Smith et al. 2005).

The current demand for formal PES market credits provided by privately owned U.S. agricultural lands has been estimated to be approximately $\$ 13.9$ billion, including demand for both water quality and carbon credits (Informa Agribusiness Consulting 2018). In the future, PES markets could play a significant role in global climate change mitigation, if structured effectively to engage producers and maintain rigor in measurement. Voluntary carbon projects have sequestered an estimated 1.2 billion $\mathrm{MtCO} 2 \mathrm{e}$ since 2006 , with a $52.6 \%$ increase in volume of voluntary carbon offsets traded between 2016 and 2018 (Ecosystem Marketplace 2019). As a multitude of actors within the hybrid governance model institute carbon-related policies to meet their commitments under the Paris Agreement, both voluntary and compliance markets may play a growing role in reducing emissions (Hamrick and Gallant 2018).

The menu of soil carbon PES options for California ranchers will soon expand dramatically, as several venture capital-backed startups have emerged offering producers compensation for soil carbon sequestration. Nori, a blockchain software company, is 
building a carbon offset marketplace that will facilitate transactions between companies voluntarily offsetting their emissions and farmers producing soil carbon offsets. Another startup, Indigo Ag, has advertised a price of \$15 per ton of soil carbon to early adopter farmers (Indigo 2019). The unprecedented flow of expertise and capital into soil carbon PES initiatives bodes well for their viability, yet the ultimate success of these efforts remains to be seen. In contrast to the independent approach of these startups, the focus of this case study is a crosssector, collaborative initiative aimed at working lands PES: the ESMC.

\section{METHODS}

\section{Case study}

The ESMC is a new PES market initiative focused on agricultural lands soil carbon, water quality, and water quantity. Participants include 48 companies and organizations from the food and agriculture industries (Appendix 1), including General Mills, McDonald's, Bayer, Cargill, Danone, and NGOs like The Nature Conservancy. Launched by the Noble Research Institute, the ESMC was convened to develop a national soil carbon and water credit protocol for ranchers and farmers. This protocol is being piloted across 28,328 hectares (70,000 acres) in Texas and Oklahoma with an official market launch set for 2022 (ESMC). The final protocol will be locally calibrated across several regions in the U.S. to account for diverse geographies as well as row crop and livestock production systems. As a broad consortium, the ESMC integrates soil expertise from across members by pooling technical knowledge toward the development of a consensus protocol. We focus in this study on ESMC because of the initiative's significance as a cohort of major industry players and collaborative approach.

\section{Data collection}

This study consisted of a literature review, participant observation, and two interview campaigns (Stanford University IRB Protocol \#50991). First, we surveyed academic publications on incentive-based conservation programs available to California cattle ranchers. We then used participant observation to understand current trends in compensating ranchers for ecosystem services by attending gatherings of the regenerative agriculture community, including the 2019 Grassfed Exchange conference in Santa Rosa, CA and the 2019 Regenerative Food Systems Investment Forum in Oakland, CA. The two lead authors also attended the first annual members-only meeting of the ESMC in Chicago, IL in August 2019 to understand the current state of the market's development and to connect with members for interview follow-up. Establishing an informal partnership with the ESMC aided the team in securing the draft market protocol, which helped to frame subsequent interviews with ranchers regarding this new opportunity.

Finally, we conducted two interview campaigns $(n=24)$ with distinct target populations using semistructured, phone-based interviews (see Appendix 2 for interview protocol). The population for our first set of interviews (10 total) was ESMC members and relevant experts. Our sample population for the second set of interviews (14 total) was California cattle ranchers with over 50 cows (or 25 cow-calf pairs) grazing on their properties or on leased land.
For our rancher interviews, we used a multistage, purposive approach to sampling to secure a diversity of perspectives by avoiding sampling only members on the California Cattlemen's Association membership list. We purposively selected counties within distinct bioregions, based on those counties being (1) top 10 cattle ranching counties and (2) representative of California's ranching community. To do this, we identified the top 10 California counties by number of cattle ranches, using the USDA National Agricultural Statistics Service's 2012 Census of Agriculture. We then identified where these counties fall within the six bioregions of the state (FRAP 2017), as done by Ferranto et al. (2011), to ensure perspectives were captured across ecosystem types. We then used nonrandom selection for cluster sampling by conferring with rangeland management experts who advised the research team on which of these top 10 cattle counties best represent California's current cattle ranching communities, in terms of political, cultural, and intergenerational perspectives. Finally, we reached out to UC Cooperative Extension (UCCE) agents serving the recommended target counties and successfully established research partnerships with agents in two counties: San Luis Obispo and Merced Counties. These agents selected a sample of ranchers within their counties who met our selection criteria and represented a diversity of political inclination, cultural context, income, ranching heritage, ranch size, education level, and engagement on sustainability. The agents made the initial outreach to participate in the study. Ranchers who agreed to participate had an average ranching experience of 46 years, a diversity of operation sizes grazing on an average of 3770 hectares (9317 acres), and over half were full-time ranchers (Appendix 3).

\section{Analysis}

The two lead authors transcribed and analyzed all interviews using Nvivo 12, a Computer Assisted Qualitative Data Analysis Software (CAQDAS). Codes were developed by both coders based on perceived patterns in attitudes expressed in early interviews and refined over time as we conducted more interviews. This study engaged the grounded theory approach to theory development proposed by Glaser and Strauss (1967), which highlights the importance in sociological research of not only verifying existing theory, but also generating new theory based on collected data. This approach contrasts with logically derived or deduced assumptions that are "ungrounded" theories based on a priori assumptions. Rather than coding data prior to analysis, we used Glaser and Strauss' constant comparison method, whereby an initial set of codes are developed that reflected ideas communicated in interviews. Codes were then used to better understand the differences between subgroups using comparison across groups or categories of subjects to highlight differences in perspectives and behaviors between them (Glaser and Strauss 1967). Quotes labelled "C" in the results refer to ESMC members, while those labelled " $\mathrm{R}$ " refer to participating ranchers.

\section{Study limitations}

Because our sample of ranchers was created based on the recommendations of county-based UCCE agents, ranchers participating in this study likely had existing relationships with our partner agents. Our sample may thus exhibit a positive bias toward conservation programs. Our interview sample represents a small percentage of the California rancher population; however, because we reached a saturation point within our interviews where we heard similar responses from each additional interview, this 
Table 1. Factors motivating interviewed members to participate in Ecosystem Services Market Consortium $($ ESMC; $\mathrm{n}=10)$

\begin{tabular}{|c|c|}
\hline $\begin{array}{l}\text { Motivating Factor } \\
\text { (Mention Frequency) }\end{array}$ & Description \\
\hline Meeting corporate commitments (9) & $\begin{array}{l}\text { These responses spoke to the utility of ESMC in helping members to meet their corporate commitments (e.g., } \\
\text { environmental, social, and governance commitments, sustainable sourcing, shareholder activism), shifting } \\
\text { away from corporate social responsibility to new approaches. }\end{array}$ \\
\hline Influencing producers (9) & $\begin{array}{l}\text { These responses spoke to the challenge of influencing agricultural producers to change practices, and } \\
\text { emphasized that financing through payment for ecosystem services markets is needed to scale sustainable } \\
\text { practices. Some interviewees spoke of their interest in augmenting producers' earnings as the main motivator } \\
\text { for participating in ESMC. }\end{array}$ \\
\hline Collaboration (9) & $\begin{array}{l}\text { These responses had to do with the utility of the consortium approach in providing a single, consistent effort } \\
\text { that would bolster public confidence, particularly because of the need for alignment across the agricultural } \\
\text { industry on methodologies and reporting. }\end{array}$ \\
\hline Business strategy (8) & $\begin{array}{l}\text { These responses spoke to the role of ESMC in helping companies to be competitive, either by building long- } \\
\text { term supply chain resilience or as part of companies' publicity strategies. }\end{array}$ \\
\hline Establishing scientific protocols (10) & $\begin{array}{l}\text { These responses spoke to the member wanting to contribute to creating the quantification, verification, and } \\
\text { reporting process. Responses included the need to merge this effort with other protocols (e.g., the Science } \\
\text { Based Targets Initiative and Greenhouse Gas Protocol). }\end{array}$ \\
\hline
\end{tabular}

signaled an adequate sample size to the research team. Finally, as the two lead authors coded distinct interviews, inherent subjectivity in our interpretation of the codes may remain, even though we used intercoder reliability ratings to identify ways in which the coders perceived themes differently and then calibrated our subjectivity. We maintained a preference for Type I errors (false positives) over Type II errors (failing to detect an effect).

\section{RESULTS}

\section{Corporate supply chain sustainability}

Interviews with ESMC members revealed that several factors motivated corporations to develop an agricultural carbon credit market, including (1) carbon insetting and (2) improving producers' access to capital to enable sustainable transitions (Table 1; see Appendix 4 for relevant interview quotes).

Relevant to corporate commitments, many interviewees spoke about the utility of ESMC in helping corporations meet their carbon commitments, including through carbon insetting. For agriculture, carbon insetting is the reduction of $\mathrm{CO}_{2}$ emissions in a company's supply chain through investment in the ecosystem services of supplier farms. This contrasts with carbon offsetting, in which corporations offset their GHG emissions by purchasing externally verified carbon offsets. Insetting offers companies a flexible option to meet their environmental, social, and governance (ESG) goals while immediately reducing GHG emissions in the company's day-to-day supply chain operations. One interviewee spoke to this motivating aspect:

\section{The Science Based Targets Scope 3 emissions reduction goal ... is a big motivator for them to try to reduce their greenhouse gas footprint ... all these companies, we have emissions reduction goals that we have to meet for our public commitments. (C3)}

Notably, the term "insetting" has some vagaries in its definition (Tipper et al. 2009), with two approaches identified by the International Carbon Offset \& Reduction Alliance as being widely in use. In one definition, a corporation "invests in the development of a carbon offset project within its own supply chain and purchases all generated carbon credits to offset its operational emissions," with offsets verified by a third party. A second approach, which does not require third party verification, consists of investment "in any activity within its supply chain that generates environmental, social and/or economic value for the supplier and company" (Davies 2016:3).

How insetting is defined, and the corollary requirements associated with producing carbon insets, have implications for the investment required to generate these assets. Through the ESMC market, farmers and ranchers can produce both carbon insets (tier 1 assets) or carbon offset credits (tier 2 assets), based on the Intergovernmental Panel on Climate Change (IPCC) tiered system for evaluating the uncertainty of emissions data for national GHG inventories. Although both tier 1 and tier $2 \mathrm{GHG}$ assets are considered to be equivalent to one metric ton of sequestered carbon dioxide equivalent $(\mathrm{CO} 2 \mathrm{e})$, tier 2 assets demand a higher level of monitoring, reporting, and verification (MRV), including site-specific data from producers and verification by an accredited third party. The more stringent regulation of tier 2 assets allows them to be traded as carbon offset credits on carbon markets. At the same time, the augmented MRV costs associated with tier 2 asset production pose a significant challenge to the scalability of agricultural soil carbon markets like ESMC.

In the context of rangelands, carbon insetting could include implementing practices that might lower $\mathrm{CO}_{2}$ emissions, including compost application and cover cropping. Such practices can also improve the resilience of an operation to extreme weather events by improving soil health, which could also support both climate change adaptation and mitigation. That said, the climate adaptation strategies used most often by California rangeland managers today are aimed at maintaining stocking flexibility, rather than augmenting soil carbon (Macon et al. 2016).

Regarding the second motivating factor of attracting financial incentives for sustainable transitions among producers, such sentiments were echoed across several interviews: "There are a lot of barriers in the way of a farmer adopting different practices, but one of the significant ones is finances. We need to find a way to bring [together] public and private and corporate interest in incentivizing better practices." (C13) 


\section{Ranchers' conservation priorities}

Like ESMC members, California cattle ranchers who participated in this study emphasized the importance of soil health. When asked "What does conservation mean to you?", we heard replies like: "Keeping it open, keeping it intact, keeping some sort of grazing animals on there for the grass and hopefully doing it in a regenerative manner and in a way that's building soil health and reducing erosion, increasing soil water-holding capacity" (R15). Although interviewed ranchers valued soil health, they did not describe the stewardship of this natural resource as a climatechange related goal but as a crucial aspect of a wider web of ecosystem services that safeguard profitability and preserve operations for the next generation.

Overall, ranchers identified two principal conservation goals for their operations: (1) protecting ecosystem services such as biodiversity, clean water, and healthy soils, and (2) preventing commercial development and preserving the ranch for the next generation, both from an ecological and a financial sustainability perspective (Table 2). Many interviewed ranchers have engaged NRCS programs for achieving these conservation goals, with NRCS's EQIP the most commonly used conservation financing program and eco-certifications the least popular among interviewees.

Table 2. Conservation priorities cited by interviewed ranchers ( $\mathrm{n}$ $=13$ ). The priorities below were cited by study participants in response to the question: "What does conservation on ranches mean to you?"

\begin{tabular}{|c|c|}
\hline $\begin{array}{l}\text { Priority } \\
\text { (Mention } \\
\text { Frequency) }\end{array}$ & $\begin{array}{l}\text { Example Quotes } \\
(\mathrm{R}=\text { participant rancher })\end{array}$ \\
\hline $\begin{array}{l}\text { Ecosystem } \\
\text { services (11) }\end{array}$ & $\begin{array}{l}\text { For me it's about stewardship of the land. It's about } \\
\text { protecting, preserving, and enhancing the health and soil } \\
\text { of the land and to pass it down to the next generation in } \\
\text { better condition than what we inherited with. (R7) }\end{array}$ \\
\hline
\end{tabular}

We can't just use up these natural resources and expect them to come back. (R9)

Soil health (10) Trying to minimize soil erosion. (R2)

With the water development and the cross-fencing, we're able to really control the grazing to a large degree. We don't want bare ground. We want to definitely leave a lot of grass, a lot of thatch on the ground so that when it does rain, we don't have a lot of erosion. (R4)

Conservation is not having it being able to wash away because if the soil leaves me, I don't have it anymore. It goes to somebody else. (R12)

Preservation (5) I had to leave Southern California because of encroachment of Los Angeles. First thing I think about is not paving over the ranch land or putting more houses on it ... We used to hear cows at night and now we hear tractors. ( $\mathrm{R} 10)$

I'm the fifth generation and my grandfather was an old dairyman... for me, another definition of sustainability is if I can pass this on to my daughter and she can run it. (R2)
When presented with a brief description of the new ESMC model, all ranchers who participated in this study $(n=14)$ expressed interest in engaging with such a carbon credit market, as long as the market was scientifically backed and the compensation they received commensurate with effort. Ranchers' reservations about participating in agricultural carbon markets included whether the science was certain around soil carbon sequestration on California rangelands, and, echoing sentiments from ESMC members, addressing possible risks to producers, some inherent to the California climate:

If a person had joined [ESMC] in 2011 or 2012 when
the drought began, I would think that they would be
considered the worst land manager ever, because their
Residual Dry Matter and all that. We just did not have
the seed growth because we didn't have the rain ... The
last few years you would have looked like a superstar...
those drought years were tough ... if you'd had an added
cost for this program and you were counting on credits
that didn't come, that could be crippling. So that would
all have to be figured out. (R8)

Further qualitative data from interviews in support of these findings can be found in Appendix 5.

\section{Demand for conservation financing outpaces supply}

California ranchers interviewed in this study expressed a willingness to change their practices if the payment offered was sufficient to cover the labor, equipment, and time costs associated with the transition to new practices, as well as the financial risks associated with practice adoption before the carbon payments are realized. If market architects, governments, or other partners are willing to fund that transition, then the shared goals of improving soil health and long-term climate resilience on managed rangelands could be achievable.

Across the conservation community, there is consensus that new funding sources are required if conservation goals are to be achieved (Echols et al. 2019). Although some interview participants had used government conservation programs, only a portion of applications across California are funded each year. For example, approximately $41 \%$ of the California EQIP applications were funded in 2019, with just over a third of the funding going to beef and dairy operations (USDA-NRCS 2019, unpublished EQIP, CSP, producer, contract, and application data from FY 2009 to FY 2019). Based on our analysis of the 2019 applications for EQIP and CSP in California (Table 3), we estimate unmet EQIP and CSP demand in the state to be over $\$ 135$ million. This can be thought of as over $\$ 135$ million in unmet demand from California producers for conservation funding. Because EQIP contracts generally mandate a cost-share component requiring the producer to spend 25 to $50 \%$ of the full project cost out-of-pocket, total demand for funding is likely even higher, because many growers would not apply in the first place given the upfront costs required to fulfill the cost-share component. With this conservative estimate of demand from California producers for conservation funding, we can better understand the need for hybrid funding and the importance of a new tool like carbon markets in filling this financial gap. 
Table 3. Estimated supply and demand for sample Natural Resources Conservation Service (NRCS) conservation programs in California (2019).

\begin{tabular}{|c|c|c|c|c|c|}
\hline Program & $\begin{array}{l}\text { Number of } \\
\text { Applicants }\end{array}$ & $\begin{array}{c}\text { Total } \\
\text { Funding Awarded }\end{array}$ & $\begin{array}{c}\text { Number of } \\
\text { Unsuccessful } \\
\text { Applications }^{\dagger}\end{array}$ & $\begin{array}{l}\text { Average Contract } \\
\text { Size }\end{array}$ & Estimated Unmet Demand \\
\hline $\begin{array}{l}\text { Environmental Quality } \\
\text { Incentives Program (EQIP) }\end{array}$ & 4070 & $\$ 91,749,629$ & 2049 & $\$ 55,238$ & $\$ 133,068,342$ \\
\hline $\begin{array}{l}\text { Conservation Stewardship } \\
\text { Program (CSP) }\end{array}$ & 106 & $\$ 2,424,727$ & 55 & $\$ 47,544$ & $\$ 2,614,920$ \\
\hline TOTAL & 4176 & $\$ 94,174,356$ & 2464 & $\$ 102,782$ & $\$ 135,683,262$ \\
\hline
\end{tabular}

\section{DISCUSSION}

Policy alignment: shared goals for improving soil health In this study we provide evidence that stakeholders with distinct motivations, e.g., corporations managing for greenhouse gas emissions and ranchers planning ahead for the next generation, can be aligned around a shared interest in soil health. Although the commodity of interest for companies buying offsets is measurable carbon, corporations and ranchers share a broader set of target outcomes: improved soil health, fertility, and prevented erosion. Notably, this broader suite of outcomes is not directly addressed by the carbon market mechanism with its focus on carbon credits, but it is of common interest to ESMC members and ranchers.

For California, we believe that carbon insetting investments by corporations hold more promise for climate change adaptation than mitigation. Soil carbon and soil health goals are often linked in corporate communications and policies like California's Healthy Soils Initiative, because there is significant overlap in activities that improve soil health and those that increase soil carbon. Yet improved soil health does not necessarily equate to measurable soil carbon sequestration, in part because soil health is a broad term that can be measured in varied ways, depending on the specific goals of interest to the landowner (Doran and Zeiss 2000). Additionally, many agricultural practices aimed at improving sequestration have produced inconclusive results in tests on California rangelands, demonstrating the challenges of carbon additionality when specific practices are applied across California's variable landscape and climate (Booker et al. 2013, Briske et al. 2014, Delonge et al. 2014, Delonge and Basche 2018). Notably, the most promising opportunity for preventing greenhouse gas emissions from California rangelands is protecting existing carbon sinks (Diaz et al. 2012, Booker et al. 2013, Teague and Barnes 2017) by preventing development and soil erosion (Gosnell and Travis 2005, Diaz et al. 2012, Booker et al. 2013).

Given the uncertainty of carbon additionality on California rangelands, aspects of soil health will most likely be improved more than soil organic carbon will be augmented following management changes. Improved soil management can have a measurable, positive effect on soil fertility, agricultural productivity, and overall climate resilience (Bradford et al. 2019).
As such, a rancher is more likely to achieve soil health goals than produce a tradable carbon-related commodity or contribute to a corporation's climate change mitigation goals. Corporate insetting efforts that improve soil management can build ranchlevel resilience to climate change by reducing soil erosion and stabilizing yields (Bradford et al. 2019). Thus, rancher's soil health goals can be enabled by both corporate carbon insetting investments as well as NRCS programs like EQIP that support soil health and ranch productivity.

\section{Policy complementarity within the hybrid governance model}

The hybrid environmental governance model suggests that, when policies instituted by various actors interact synergistically, they can overcome the limitations of any single policy (Nagendra and Ostrom 2012). The myriad policy tools available to ranchers today that support soil health bring with them unique benefits and challenges, summarized in Table 4 (based on literature and our interviews). For example, while carbon markets may unlock financing and enable ranchers to scientifically track soil health indicators over time, they have generally allocated the upfront financial risk to producers. Policies can relieve some of this burden by transferring risk away from landowners to other actors in the supply chain. Other practice-based, government-led PES programs can also help to ease ranchers' entry into outcomebased carbon markets, as with NRCS's Conservation Innovation Grants (CIG) On-Farm Trials program, which mitigates risk placed on producers through incentive payments for conservation practices. USDA programs like CSP and EQIP can provide direct grant support to farmers as they adopt new management practices, regardless of how much additional carbon is sequestered. Future USDA programs could further derisk the process for producers by offering technical or financial support for participation in PES markets, for example, to defray the costs of monitoring (e.g., engaging contractors and laboratories to develop soil sampling plans and collect and process soil samples). Within the hybrid governance model, public programs play an important role in providing financial and technical support so that producers can more easily make soil health and adaptationrelated investments.

\section{Hybrid conservation financing}

If ESMC and other new programs within the hybrid governance model are able to address current barriers to participation, for 
Table 4. Evaluating policy alignment around soil health on California ranches.

\begin{tabular}{|c|c|c|c|}
\hline & $\begin{array}{l}\text { Government Programs } \\
\text { (e.g., Farm Bill Programs) }\end{array}$ & $\begin{array}{l}\text { Price Premiums } \\
\text { (e.g., USDA Organic) }\end{array}$ & $\begin{array}{l}\text { PES Markets } \\
\text { (e.g., Carbon Markets) }\end{array}$ \\
\hline Benefits & $\begin{array}{l}\text { Capital: Provide financial support for } \\
\text { interventions related to ecosystem health or } \\
\text { prevented development } \\
\text { Adaptation: Financial and technical support } \\
\text { for building ranch resilience (e.g., managing } \\
\text { for invasive plants) } \\
\text { Risk mitigation: Provides upfront capital to } \\
\text { producers transitioning to carbon markets }\end{array}$ & $\begin{array}{l}\text { Capital: Increased income to producers } \\
\text { Adaptation: Additional income can be } \\
\text { reinvested into the operation and } \\
\text { practices that support soil health }\end{array}$ & $\begin{array}{l}\text { Capital: Carbon offset income can meet } \\
\text { demand for soil health financing } \\
\text { Adaptation: Additional soil carbon can } \\
\text { increase resilience and ranch productivity } \\
\text { Data: Improved access to soil health data to } \\
\text { better assess changes over time and the } \\
\text { impact of new practices }\end{array}$ \\
\hline \multirow[t]{3}{*}{ Challenges } & $\begin{array}{l}\text { Paperwork burden (especially for new } \\
\text { participants) } \\
\text { Limited funding }\end{array}$ & $\begin{array}{l}\text { Paperwork burden } \\
\text { Rancher effort and time to adopt new } \\
\text { practices }\end{array}$ & $\begin{array}{l}\text { Carbon additionality is difficult to measure } \\
\text { and monitor, and not guaranteed with } \\
\text { changes in practices }\end{array}$ \\
\hline & $\begin{array}{l}\text { Prescriptive approaches are sometimes } \\
\text { required that are shaped by agency staff } \\
\text { unfamiliar with specific ranches' contexts }\end{array}$ & $\begin{array}{l}\text { Infrastructure: Limited access to } \\
\text { processing facilities and USDA } \\
\text { inspectors can create a supply chain } \\
\text { bottleneck }\end{array}$ & $\begin{array}{l}\text { Transfer of responsibility from credit } \\
\text { buyers to ranchers ("greenwashing") } \\
\text { Risk: Transition risk is often placed on } \\
\text { producers }\end{array}$ \\
\hline & $\begin{array}{l}\text { Information can be difficult to access (e.g., } \\
\text { complex terminology, lack of agency } \\
\text { outreach due to understaffing) } \\
\text { Complexity: Easements require a complex } \\
\text { legal and funding process that often takes } \\
\text { years to complete }\end{array}$ & $\begin{array}{l}\text { Logistics: Most cow-calf or stocker } \\
\text { operations are by definition not } \\
\text { managing cattle for their full life cycles, } \\
\text { as might be required by certifications }\end{array}$ & $\begin{array}{l}\text { Values: Rewarding "bad players" more than } \\
\text { "good players" }\end{array}$ \\
\hline
\end{tabular}

example, by decreasing the administrative burden placed on producers, they could address both the financial risks and nonmonetary barriers that prevent ranchers from participating in conservation programs. Should improvements like crossfencing and improved grazing management that are supported by NRCS programs lead to improved soil carbon levels, ranchers could be rewarded for the additional carbon through PES markets. Such income could support future ranch improvements in operational efficiency, profitability, and carbon sequestration potential. In this scenario, the ESMC could particularly help to meet demand for conservation financing for several types of ranchers: (1) those fronting their personal share of NRCS costshare programs, (2) applicants who are rejected from government conservation programs, or (3) those averse to government-led programs.

Payments from PES markets are generally made only after producers have implemented new conservation-based practices, which requires upfront expense. Adoption of new practices may therefore require the incentive of additional financial support beyond carbon credits. For instance, PES carbon markets might be especially attractive to ranchers if they had guaranteed, i.e., noncompetitive, access to affordable capital to derisk practice transitions and support the upfront costs of new practice adoption. Accessible conservation finance can take many forms, including a philanthropic or corporate sponsored grant, a lowcost loan from an impact investor, or a revolving pool of credit in partnership with NRCS funding (Encourage Capital 2017). As Encourage Capital (2017) identified, some conservation practices could offer investors a return on their capital, for example through organic transitions. A revolving pool of low-cost credit could supplement cost-share portions of government programs and free more public funding to meet rancher demand, helping every public dollar go further. Most importantly, such a mechanism could align corporate goals of providing financial incentives for producer behavior change with ranchers' priorities around safeguarding the profitability of their operations.

Producers unable to access public funding can increasingly turn to private sources of capital that mitigate economic risk (see Fig. 2). Many innovative conservation financing mechanisms are in development today, including by ESMC member Danone North America, which has marketed a \$20 million partnership with rePlant Capital to support farmers transitioning to regenerative and organic practices. Other stakeholders providing financial support to producers for transitioning include investment funds like Foodshed Investors, Rabo Agrifinance and Pipeline Foods' Organic Transition Loan, and crowdfunding platforms that connect lenders to growers. Innovative conservation financing can help to derisk the onboarding process for ranchers participating in carbon markets and implementing new soil health practices. Agricultural carbon market architects could play a role in establishing or supporting the creation of such mechanisms.

\section{Unknowns and opportunities}

With financial incentives potentially motivating producers to adopt conservation practices, the price that corporations pay farmers for generated credits will determine in part the feasibility of any agricultural soil carbon market. Whether the ESMC market will lead to observable changes in soil health and improved rangeland management practices is contingent on whether ranchers decide that the risk, including cost, time, and labor, is worth the anticipated carbon market payout. The carbon price 
required to incentivize adoption of new management practices varies from rancher to rancher. For example, one participant told us that " $\$ 3-\$ 5$ an acre would be a big deal" (R13), while another rancher explained that " $\$ 15-20$ per metric ton of carbon is never going to be enough money ... if we really want to see some incentive programs for ranchers that get to the next step, it needs to be more like $\$ 70, \$ 80$ a metric ton" (R15). Ranchers who are more financially dependent on agricultural activities for income may require a higher price point to participate in carbon markets. California ranchers often invest in conservation on their properties without expected financial return; yet participation rates will likely remain low if compensation is not adequate to incentivize participation. The low rate at which ranchers participate in conservation programs historically (Didier and Brunson 2004, Cheatum et al. 2011, Farley et al. 2017) indicates a significant obstacle for carbon markets to influence rangeland management practices.

Fig. 2. Annual budgets of sample financers of rangelands soil health. Source: Forest Trends 2013, Encourage Capital 2017, SBCFA and Armonia LLC 2017, Valoral Advisors 2018, TNC 2019, USDA 2020

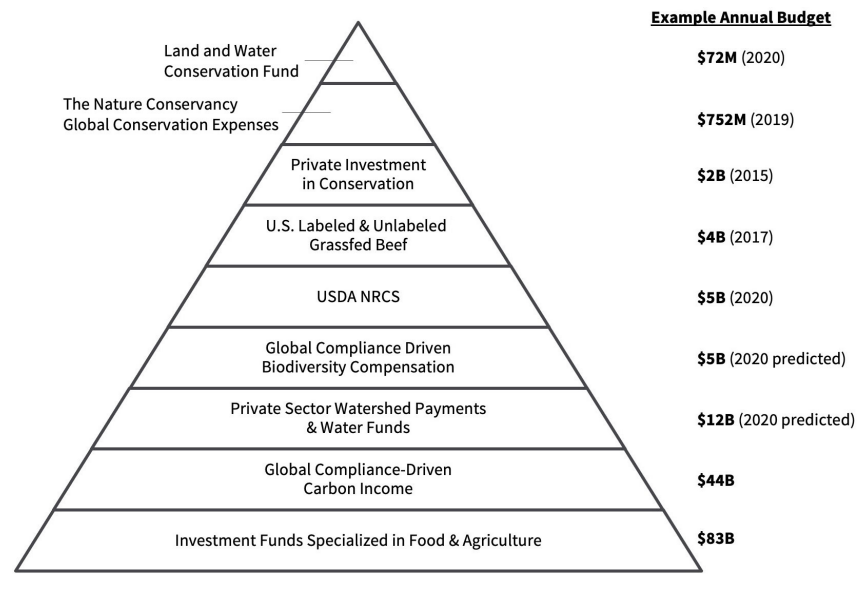

Beyond price, a related question raised by several interviewed ESMC members is the uncertain demand for rangelands-derived carbon offsets: "The most important piece is: What's the demand? We can set up protocols, we can find farmers, we can get pilots done, but who's going to ultimately buy from this market?" (C5). National climate policy could influence future carbon offset demand, for example if a national carbon tax were to become reality. At the same time, the impacts of a national carbon tax on intensive agriculture and subsequent impact on rangeland-based operations is uncertain, but could be non-negligible given the pressure it would put on commercial feedlots that rely heavily on industrially produced corn (Booker et al. 2013). Future federal or state regulations focused on soil erosion, agricultural land conversion, habitat conservation, water, or nutrient losses could also influence producers' interest and ability to engage in ESMC or other PES markets. In the absence of dependable demand for carbon offset credits, ESMC members may need to provide the initial investment for insetting goals to achieve soil health targets, filling the financial gap until a consistent pipeline of credit buyers is established.
Finally, PES market success for rangeland soil carbon is dependent on the scalability and affordability of accurate soil carbon monitoring technologies. Quantifiable indicators monitored over time are required to define and measure policy success, particularly in an outcome-based market environment. Given the costs and challenges of measuring soil carbon across the heterogeneous rangelands of California, this task appears more challenging than measuring soil productivity, an outcome that can be tracked by satellites, drones, and greenness at-scale. Through its collaborative approach and aggregated expertise, ESMC is well positioned to develop monitoring protocols that are scalable and accurate in measuring soil carbon change.

\section{Considering the trade-offs of conservation policy}

Investments in ranch resilience can support multiple conservation-related goals associated with preserving natural resources and safeguarding on-farm productivity and profitability (Derner et al. 2018, Gosnell et al. 2020). At the same time, one should also note the environmental harms that can result from activities aimed at increasing soil carbon and the possibility of negative interactions between policies that work at crosspurposes. These situations present conservation decision makers with important trade-offs to consider. Although policies aimed at sustainability on working lands are generally not antagonistic in nature (Lambin and Thorlakson 2018), some conservationfocused activities can negatively impact other conservation outcomes (Buckley Biggs and Huntsinger 2021). Two examples of such trade-offs are when increases in soil fertility result in diminished plant diversity (Harpole et al. 2016) and when organic amendments lead to increased soil lead or nitrate and phosphorus runoff (Gravuer et al. 2019). Landowners and society at large value rangelands for an array of conservation values, including water quality, endangered species habitat, native plants, etc. The difficulty of augmenting soil carbon on many California rangelands may signal a misalignment between PES programs aimed solely at soil carbon and the broader suite of conservation goals for California's working lands.

\section{CONCLUSION}

In the context of the hybrid environmental governance model, we used two criteria to evaluate ex-ante the potential impact of a new agriculture industry-led PES market: (i) policy alignment and (ii) policy complementarity. We explored the challenges and opportunities of rangelands soil carbon PES based on alignment between ranchers' soil health priorities and corporate sustainability goals, as well as the intersection of PES markets and existing conservation policies.

A policy's goals can at times diverge from those of its target participants, yet some alignment is required for policy traction, especially for voluntary initiatives. This study has shown that, while the intent of carbon markets may be climate change mitigation, the ranchers it aims to engage are more concerned about the long-term stewardship of land resources, ranch productivity and profitability, and resilience. PES market developers are highly motivated by the opportunity to drive behavior change among producers and to meet corporate carbon insetting goals. Insetting, with its focus on building resilience into agricultural supply chains, appears to be a climate change adaptation measure that is well aligned with ranchers' goals of improving ranch resilience. These ranch-level goals are otherwise 
enabled by funding or educational programs such as California's Healthy Soils Program and conservation programs run by the Extension Service or NRCS that support grazing management and soil health.

Regarding policy complementarity, the likelihood of success of new PES tools like ESMC's carbon market depends on how well they address the gaps and barriers to participation left by existing conservation programs, including regulatory burdens, lack of transparency, or low producer involvement. The PES market evaluated here could help meet the current demand for conservation financing, particularly for ranchers whose NRCS program applications are rejected or who are averse to participating in government programs. In cases where improvements subsidized by NRCS programs allow for augmented soil carbon, ranchers would be rewarded through PES markets. If compensation for sequestered carbon were adequately high, the additional income for ranchers could not only enable infrastructure developments that remain unfunded by public programs, but could also contribute to the overall financial outlook of ranches already operating at low margins. The outcome-based structure of the ESMC market fits with California's highly variable climate by allowing for adaptive management by ranchers. Government programs supporting soil health goals and private sector PES markets have important areas of complementarity within the hybrid governance structure and engage the diverse capabilities of a variety of actors, from the agriculture industry's research expertise and supply chain influence to producer associations' farm-level relationships.

Nonetheless, significant challenges surround the implementation of soil carbon PES markets, including identifying buyers of rangelands-derived carbon credits, managing the financial risk placed on producers as they adopt new practices, and the difficulty of augmenting soil carbon on many California rangelands due to their nonequilibrium nature. The carbon offset market structure may be limited in its ability to support the goals shared by cattle ranchers and corporations because of its dependence on uncertain demand and prices for rangelands carbon offsets, as well as its parochial focus on a decadal increase in soil carbon rather than a broader suite of landscape goals like improved soil health or prevented erosion. Providing an adequately high price point to ranchers to incentivize participation is essential to policy traction and upscaling. To successfully build ranch-level resilience to climate change, the ESMC and other emerging agricultural carbon markets should expand their local engagement with ranchers, extension agents, and other experts in the market development process.

Although the increased weather variability associated with climate change threatens the financial viability of cattle ranches today (Bastian et al. 2018), climate change is also unlocking new forms of capital that ranchers can access, from PES markets to investments by the financial industry in working lands. With any of these programs, more ranchers will likely participate if communications and materials speak not just to climate change but to the management goals that resonate most with the ranching community: building soil health, preventing erosion, and passing along the ranch in good condition to the next generation.
Responses to this article can be read online at: https://www.ecologyandsociety.org/issues/responses. $\mathrm{php} / 12254$

\section{Acknowledgments:}

This work was made possible by generous funding from the Anne and Reid Buckley Fund in Support of Stanford University's Emmet Interdisciplinary Program in Environment \& Resources (E-IPER) and the Emmett Family Collaboration Grant Fund. We are grateful for the contributions of our project collaborators and advisors: Dr. Royce Larsen at the UC Cooperative Extension and Dr. Jeremy Bulow, as well as Dr. Gabrielle Wong-Parodi and Stephanie Fischer for their guidance on the qualitative coding process. Our sincere thanks go to the anonymous reviewers.

\section{Data Availability:}

The interview data that support the findings of this study are not available because they contain information that could compromise the privacy of research participants, given the small populations from which participants were sampled.

\section{LITERATURE CITED}

Abdalla, M., A. Hastings, D. R. Chadwick, D. L. Jones, C. D. Evans, M. B. Jones, R. M. Rees, and P. Smith. 2018. Critical review of the impacts of grazing intensity on soil organic carbon storage and other soil quality indicators in extensively managed grasslands. Agriculture, Ecosystems and Environment 253:62-81. https://doi.org/10.1016/j.agee.2017.10.023

American Farmland Trust. 2012. California agricultural vision: from strategies to results. American Farmland Trust, Davis, California, USA. [online] URL: http://www.cdfa.ca.gov/ agvision/docs/Ag_Vision_Progress_Report.pdf

Aoyama, L., and L. Huntsinger. 2019. Are landowners, managers, and range management academics on the same page about conservation? Rangelands 41(1):61-69. https://doi.org/10.1016/j. rala.2018.10.001

Barnette, W., P. Matson, J. Novy-Hildesley, and J. Mason. 2016. Global fisheries: the emergence of a sustainable seafood movement. (Case No. SI-141). Graduate School of Stanford Business, Stanford, California, USA.

Bastian, C. T., J. P. Ritten, and J. D. Derner. 2018. Ranch profitability given increased precipitation variability and flexible stocking. Journal of ASFMRA 122-139.

Blomquist, J., V. Bartolino, and S. Waldo, 2015. Price premiums for providing eco-labelled seafood: evidence from MSC-certified cod in Sweden. Journal of Agricultural Economics 66(3):690-704. https://doi.org/10.1111/1477-9552.12106

Booker, K., L. Huntsinger, J. W. Bartolome, N. F. Sayre, and W. Stewart. 2013. What can ecological science tell us about opportunities for carbon sequestration on arid rangelands in the United States? Global Environmental Change 23:240-251. https:// doi.org/10.1016/j.gloenvcha.2012.10.001 
Börner, J., and S. A. Vosti. 2013. Managing tropical forest ecosystem services: an overview of options. Pages 21-46 in R. Muradian and L. Rival, editors. Governing the provision of ecosystem services. Springer, Dordrecht, The Netherlands. https:// doi.org/10.1007/978-94-007-5176-7 2

Bossio, D. A., S. C. Cook-Patton, P. W. Ellis, J. Fargione, J. Sanderman, P. Smith, S. Wood, R. J. Zomer, M. von Unger, I. M. Emmer, and B. W. Griscom. 2020. The role of soil carbon in natural climate solutions. Nature Sustainability 3:391-398. https:// doi.org/10.1038/s41893-020-0491-Z

Bradford, M. A., C. J. Carey, L. Atwood, D. Bossio, E. P. Fenichel, S. Gennet, J. Fargione, J. R. B. Fisher, E. Fuller, D. A. Kane, et al. 2019. Soil carbon science for policy and practice. Nature Sustainability 2:1070-1072. https://doi.org/10.1038/s41893-019-0431y

Brain, R. G., M. E. Hostetler, and T. A. Irani. 2014. Why do cattle ranchers participate in conservation easement agreements? Key motivators in decision making. Agroecology and Sustainable Food Systems 38(3):299-316. https://doi.org/10.1080/21683565.2013.819479

Briske, D. D., A. J. Ash, J. D. Derner, and L. Huntsinger. 2014. Commentary: a critical assessment of the policy endorsement for holistic management. Agricultural Systems 125:50-53. https://doi. org/10.1016/j.agsy.2013.12.001

Buckley, K. J., P. Newton, H. K. Gibbs, I. McConnel, and J. Ehrmann. 2019. Pursuing sustainability through multistakeholder collaboration: a description of the governance, actions, and perceived impacts of the roundtables for sustainable beef. World Development 121:203-217. https://doi.org/10.1016/j. worlddev.2018.07.019

Buckley Biggs, N., and L. Huntsinger. 2021. Managed grazing on California annual rangelands in the context of state climate policy. Rangeland Ecology \& Management, in press.

California Air Resources Board (CARB). 2019. January 2019 draft: California 2030 natural and working lands climate change implementation plan. CARB, Sacramento, California, USA. [online] URL: https://ww3.arb.ca.gov/cc/natandworkinglands/ draft-nwl-ip-1.3.19.pdf

California Department of Food and Agriculture (CDFA). 2020. Healthy soils program. CDFA, Sacramento, California, USA. [online] URL: https://www.cdfa.ca.gov/oefi/healthysoils

Carey, C., K. Gravuer, S. Gennet, D. Osleger, and S. Wood. 2020. Supporting evidence varies for rangeland management practices that seek to improve soil properties and forage production in California. California Agriculture 74(2):101-111. https://doi. org/10.3733/ca.2020a0015

Chan, K. M. A., T. Satterfield, and J. Goldstein. 2012. Rethinking ecosystem services to better address and navigate cultural values. Ecological Economics 74:8-18. https://doi.org/10.1016/j. ecolecon.2011.11.011

Cheatum, M., F. Casey, P. Alvarez, and B. Parkhurst. 2011. Payments for ecosystem services: a California rancher perspective. Conservation Economics White Paper. Conservation Economics and Finance Program. Defenders of Wildlife, Washington, D.C., USA. [online] URL: https://carangeland.org/images/ payments for ecosystem services a california rancher perspective. pdf

Chinangwa, L., A. Gasparatos, and O. Saito. 2017. Forest conservation and the private sector: stakeholder perceptions towards payment for ecosystem service schemes in the tobacco and sugarcane sectors in Malawi. Sustainability Science 12:727-746. https://doi.org/10.1007/s11625-017-0469-6

Climate Action Reserve (CAR). 2019. Standardized GHG accounting for soil organic carbon accrual on non-forest lands: challenges and opportunities. Discussion paper. CAR, Los Angeles, California, USA. [online] URL: https://www. climateactionreserve.org/wp-content/uploads/2019/09/Soil-OrganicCarbon-Accrual-Scoping-Paper.pdf

Conte, M., E. Nelson, K. Carney, C. Fissore, N. Olwero, A. J. Plantinga, B. Stanley, and T. Ricketts. 2011. Terrestrial carbon sequestration and storage. Pages 111-128 in P. Kareiva, H. Tallis, T. Ricketts, G. Daily, and S. Polasky, editors. Natural capital: theory and practice of mapping ecosystem services. Oxford University Press, New York, New York, USA. https://doi. org/10.1093/acprof:oso/9780199588992.003.0007

Corbera, E., C. G. Soberanis, and K. Brown. 2009. Institutional dimensions of payments for ecosystem services: an analysis of Mexico's carbon forestry programme. Ecological Economics 68 (3):743-761. http://dx.doi.org/10.1016/j.ecolecon.2008.06.008

Crowley, M. A., K. E. Shannon, I. S. Leslie, A. Jilling, C. D. McIntire, and E. Kyker-Snowman. 2019. Sustainable beef production in New England: policy and value-chain challenges and opportunities. Agroecology and Sustainable Food Systems 43 (3):274-298. https://doi.org.stanford.idm.oclc.org/10.1080/2168$\underline{3565.2018 .1492494}$ https://doi.org/10.1080/21683565.2018.1492494

Daily, G. C. 1997. Nature's services: societal dependence on natural ecosystems. Island, Washington, D.C., USA.

Dauvergne, P., and J. Alger, editors. 2018. A research agenda for global environmental politics. Edward Elgar, Cheltenham, UK. https://doi.org/10.4337/9781788110952

Davies, M. 2016. Insetting: developing carbon offset projects within a company's own supply chain and supply chain communities. International Carbon Reduction and Offset Alliance, Geneva, Switzerland. [online] URL: https://www.icroa.org/resources/ Pictures/ICROA \%20Insetting\% 20Report v300.pdf

Delonge, M., and A. Basche. 2018. Managing grazing lands to improve soils and promote climate change adaptation and mitigation: a global synthesis. Renewable Agriculture and Food Systems 33(3):267-278. https://doi.org/10.1017/S1742170517000588

Delonge, M. S., J. J. Owen, and W. L. Silver. 2014. Greenhouse gas mitigation opportunities in California agriculture: review of California rangeland emissions and mitigation potential. Nicholas Institute for Environmental Policy Solutions, Duke University, Durham, North Carolina, USA.

Derner, J. D., A. J. Smart, T. P. Toombs, D. Larsen, R. L. McCulley, J. Goodwin, S. Sims, and L. M. Roche. 2018. Soil health as a transformational change agent for US grazing lands management. Rangeland Ecology \& Management 71(4):403-408. https://doi.org/10.1016/j.rama.2018.03.007 
di Virgilio, A., S. A. Lambertucci, and J. M. Morales. 2019. Sustainable grazing management in rangelands: over a century searching for a silver bullet. Agriculture, Ecosystems \& Environment 283:106561. https://doi.org/10.1016/j.agee.2019.05.020

Diaz, D., B. Rashford, S. De Gryze, and S. Zakreski. 2012. Evaluation of avoided grassland conversion and cropland conversion to grassland as potential carbon offset project types. Issue paper prepared for the Climate Action Reserve. The Climate Trust, Portland, Oregon, USA.

Didier, E. A., and M. W. Brunson. 2004. Adoption of range management innovations by Utah ranchers. Rangeland Ecology and Management 57(4):330-336. https://doi.org/10.2111/1551-5028 (2004)057[0330:AORMIB]2.0.CO;2

Doran, J. W., and M. R. Zeiss. 2000. Soil health and sustainability: managing the biotic component of soil quality. Applied Soil Ecology 15(1):3-11. https://doi.org/10.1016/S0929-1393(00)00067-6

Echols, A., A. Front, and J. Cummins. 2019. Broadening conservation funding. Wildlife Society Bulletin 43(3):372-381. https://doi.org/10.1002/wsb.1003

Ecosystem Marketplace. 2019. Financing emissions reductions in the future: state of the voluntary carbon markets 2019. Forest Trends, Washington, D.C., USA.

Ecosystem Services Market Consortium (ESMC). About us. ESMC. [online] URL: https://ecosystemservicesmarket.org/ about-us/

Encourage Capital. 2017. NRCS and investment capital: investing in America together. Encourage Capital, New York, New York, USA. [online] URL: http://encouragecapital.com/wp-content/ uploads/2017/09/EC Private-Capital-Report Reduced-Size 091417. pdf

Engel, S., S. Pagiola, and S. Wunder. 2008. Designing payments for environmental services in theory and practice: an overview of the issues. Ecological Economics 65(4):663-674. https://doi. org/10.1016/j.ecolecon.2008.03.011

Engler, J.-O., and H. von Wehrden. 2018. Global assessment of the non-equilibrium theory of rangelands: revisited and refined. Land Use Policy 70:479-484. https://doi.org/10.1016/j. landusepol.2017.11.026

Farley, K. A., K. Walsh, and A. S. Levine. 2017. Opportunities and obstacles for rangeland conservation in San Diego County, California, USA. Ecology and Society 22(1):38. https://doi. org/10.5751/ES-09077-220138

Ferranto, S., L. Huntsinger, C. Getz, G. Nakamura, W. Stewart, S. Drill, Y. Valachovic, M. DeLasaux, and M. Kelly. 2011. Forest and rangeland owners value land for natural amenities and as financial investment. California Agriculture 65(4):184-191. https://doi.org/10.3733/ca.v065n04p184

Follett, R. F., and D. A. Reed. 2010. Soil carbon sequestration in grazing lands: societal benefits and policy implications. Rangeland Ecology and Management 63(1):4-15. https://doi. org/10.2111/08-225.1

Forest Trends. 2013. The matrix 2013: innovative markets and market-like instruments for ecosystem services. Forest Trends,
Washington, D.C., USA. [online] URL: https://www. ecosystemmarketplace.com/wp-content/uploads/2015/09/the matrix. pdf

Forest Trends and The Ecosystem Marketplace. 2008. Payments for ecosystem services: market profiles. Forest Trends, Washington, D.C., USA.

(FRAP) CALFIRE Fire and Resource Assessment Program. 2017. California's forests and rangelands: 2017 assessment. California Department of Forestry and Fire Protection, Sacramento, California, USA.

Glaser, B. G., and A. L. Strauss. 1967. The discovery of grounded theory: strategies for qualitative research. Aldine, Chicago, Illinois, USA.

Goldstein, J. H., C. K. Presnall, L. López-Hoffman, G. P. Nabhan, R. L. Knight, G. B. Ruyle, and T. P. Toombs. 2011. Beef and beyond: paying for ecosystem services on Western US rangelands. Rangelands 33(5):4-12. https://doi.org/10.2111/1551-501x-33.5.4

Gosnell, H., K. Grimm, and B. E. Goldstein. 2020. A half century of holistic management: what does the evidence reveal? Agriculture and Human Values 37:849-867. https://doi. org/10.1007/s10460-020-10016-W

Gosnell, H., N. Robinson-Maness, and S. Charnley. 2011. Engaging ranchers in market-based approaches to climate change mitigation: opportunities, challenges, and policy implications. Rangelands 33(5):20-24. https://doi.org/10.2111/1551-501X-33.5.20

Gosnell, H., and W. R. Travis. 2005. Ranchland ownership dynamics in the Rocky Mountain west. Rangeland Ecology and Management 58(2):191-198. https://doi.org/10.2111/1551-5028 (2005) $58<191:$ RODITR $>2.0$. CO:2

Gravuer, K., S. Gennet, and H. L. Throop. 2019. Organic amendment additions to rangelands: a meta-analysis of multiple ecosystem outcomes. Global Change Biology 25(3):1152-1170. https://doi.org/10.1111/gcb.14535

Gwin, L. 2009. Scaling-up sustainable livestock production: innovation and challenges for grass-fed beef in the U.S. Journal of Sustainable Agriculture 33(2):189-209. https://doi-org. stanford.idm.oclc.org/10.1080/10440040802660095 https://doi. org/10.1080/10440040802660095

Hajjar, R., P. Newton, D. Adshead, M. Bogaerts, V. A. MaguireRajpaul, L. F. G. Pinto, C. L. McDermott, J. C. Milder, E. Wollenberg, and A. Agrawal. 2019. Scaling up sustainability in commodity agriculture: transferability of governance mechanisms across the coffee and cattle sectors in Brazil. Journal of Cleaner Production 206:124-132. https://doi.org/10.1016/j.jclepro.2018.09.102

Hamrick, K., and M. Gallant. 2018. Voluntary carbon markets: outlooks and trends. Forest Trends, Washington, D.C., USA. [online] URL: https://www.forest-trends.org/wp-content/uploads/2018/07/ VCM-Q1-Periodical Draft 7.6 full.pdf

Hansen, K., E. Duke, C. Bond, M. Purcell, and G. Paige. 2018. Rancher preferences for a payment for ecosystem services program in southwestern Wyoming. Ecological Economics 146:240-249. https://doi.org/10.1016/J.ECOLECON.2017.10.013 
Harpole, W. S., L. L. Sullivan, E. M. Lind, J. Firn, P. B. Adler, E. T. Borer, J. Chase, P. A. Fay, Y. Hautier, H. Hillebrand, A. S. MacDougall, E. W. Seabloom, R. Williams, J. D. Bakker, M. W. Cadotte, E. J. Chaneton, C. Chu, E. E. Cleland, C. D'Antonio, K. F. Davies, D. S. Gruner, N. Hagenah, K. Kirkman, J. M. H. Knops, K. J. La Pierre, R. L. McCulley, J. L. Moore, J. W. Morgan, S. M. Prober, A. C. Risch, M. Schuetz, C. J. Stevens, and P. D. Wragg. 2016. Addition of multiple limiting resources reduces grassland diversity. Nature 537:93-96. https://doi.org/10.1038/ nature19324

Haya, B., D. Cullenward, A. L. Strong, E. Grubert, R. Heilmayr, D. A. Sivas, and M. Wara. 2020. Managing uncertainty in carbon offsets: insights from California's standardized approach. Climate Policy 20(9):1112-1126. https://doi.org/10.1080/14693062.2020.1781035

Hermann, D., S. Sauthoff, and O. Mußhoff. 2017. Ex-ante evaluation of policy measures to enhance carbon sequestration in agricultural soils. Ecological Economics 140:241-250. https:// doi.org/10.1016/j.ecolecon.2017.05.018

Huntsinger, L., and J. W. Bartolome. 2014. Cows? In California? Rangelands and livestock in the Golden State. Rangelands 36 (5):4-10. https://doi.org/10.2111/rangelands-d-14-00019.1

Huntsinger, L., M. Johnson, M. Stafford, and J. Fried. 2010. Hardwood rangeland landowners in California from 1985 to 2004: production, ecosystem services, and permanence. Rangeland Ecology and Management 63(3):324-334. https://doi. org/10.2111/08-166.1

Indigo. 2019. Indigo launches Indigo Acres, a comprehensive package to support growers transitioning to regenerative farming practices. Press Release. Indigo, Boston, Massachusetts, USA. [online] URL: https://www.indigoag.com/pages/news/indigolaunches-indigo-acres

Informa Agribusiness Consulting. 2018. Economic assessment for ecosystem service market credits from agricultural working lands. Informa Agribusiness Consulting, Washington, D.C., USA. [online] URL: https://ecosystemservicesmarket.org/wp-content/ uploads/2019/09/Informa-IHS-Markit-ESM-Study-Sep-19.pdf

Jordan, A. J., D. Huitema, M. Hildén, H. van Asselt, T. J. Rayner, J. J. Schoenefeld, J. Tosun, J. Forster, and E. L. Boasson. 2015. Emergence of polycentric climate governance and its future prospects. Nature Climate Change 5:977-982. https://doi. org/10.1038/nclimate 2725

Lambin, E. F., and P. Meyfroidt. 2010. Land use transitions: socio-ecological feedback versus socio-economic change. Land Use Policy 27(2):108-118. https://doi.org/10.1016/j.landusepol.2009.09.003

Lambin, E. F., P. Meyfroidt, X. Rueda, A. Blackman, J. Börner, P. O. Cerutti, T. Dietsch, L. Jungmann, P. Lamarque, J. Lister, N. F. Walker, and S. Wunder. 2014. Effectiveness and synergies of policy instruments for land use governance in tropical regions. Global Environmental Change 28:129-140. https://doi.org/10.1016/ j.gloenvcha.2014.06.007

Lambin, E. F., and T. Thorlakson. 2018. Sustainability standards: interactions between private actors, civil society, and governments. Annual Review of Environment and Resources 43 (1):369-393. https://doi.org/10.1146/annurev-environ-102017-025931
Legislative Analyst's Office (LAO). 2017. Implementation of past natural resources bonds. LAO, Sacramento, California, USA. [online] URL: https://lao.ca.gov/handouts/resources/2017/implementationof-resources-bonds-032117.pdf

Lemos, M. C., and A. Agrawal. 2006. Environmental governance. Annual Review of Environment and Resources 31:297-325. https:// doi.org/10.1146/annurev.energy.31.042605.135621

Lubell, M. N., B. B. Cutts, L. M. Roche, M. Hamilton, J. D. Derner, E. Kachergis, and K. W. Tate. 2013. Conservation program participation and adaptive rangeland decision-making. Rangeland Ecology \& Management 66(6):609-620. https://doi. org/10.2111/REM-D-13-00025.1

Macon, D. K., S. Barry, T. Becchetti, J. S. Davy, M. P. Doran, J. A. Finzel, H. George, J. M. Harper, L. Huntsinger, R. S. Ingram, D. E. Lancaster, R. E. Larsen, D. J. Lewis, D. F. Lile, N. K. McDougald, F. E. Mashiri, G. Nader, S. R. Oneto, J. W. Stackhouse, and L. M. Roche. 2016. Coping with drought on California rangelands. Rangelands 38(4):222-228. https://doi. org/10.1016/j.rala.2016.06.005

Mannix, C., and L. Allison. 2018. Conservation economics on Western working lands. Western Landowners Alliance, Santa Fe, New Mexico, USA. [online] URL: https://westernlandowners. org/wp-content/uploads/2019/02/2019.02-ConservationEconomics_FINAL.pdf

McSherry, M. E., and M. E. Ritchie. 2013. Effects of grazing on grassland soil carbon: a global review. Global Change Biology 19 (5):1347-1357. https://doi.org/10.1111/gcb.12144

Mora, C. 2018. Sustainable cattle production: why certification schemes outreach is so limited and where to look forward? Sustainable Agriculture Network. [online] URL: https://www. sustainableagriculture.eco/blog/2018/5/28/sustainable-cattle-productionwhy-certification-schemes-outreach-is-so-limited-and-where-to-lookforward

Naegele, H. 2019. Where does the fairtrade money go? How much consumers pay extra for fairtrade coffee and how this value is split along the value chain. DIW Discussion Papers, No. 1783, Deutsches Institut für Wirtschaftsforschung (DIW), Berlin, Germany.

Nagendra, H., and E. Ostrom. 2012. Polycentric governance of multifunctional forested landscapes. International Journal of the Commons 6(2):104-133. https://doi.org/10.18352/ijc.321

Nahlik, A. M., M. E. Kentula, M. S. Fennessy, and D. H. Landers. 2012. Where is the consensus? A proposed foundation for moving ecosystem service concepts into practice. Ecological Economics 77:27-35. https://doi.org/10.1016/j.ecolecon.2012.01.001

National Agricultural Statistics Service (NASS). 2018. Cattle. U. S. Department of Agriculture, Washington, D.C., USA.

Natural Resources Conservation Service (NRCS). 2017. Soil health awareness - unlock the secrets in the soil. U.S. Department of Agriculture, Washington, D.C., USA. [online] URL: https:// www.nrcs.usda.gov/wps/portal/nrcs/detailfull/national/soils/health

Oba, G., N. C. Stenseth, and W. J. Lusigi. 2000. New perspectives on sustainable grazing management in arid zones of Sub-Saharan 
Africa. BioScience 50(1):35-51. https://doi.org/10.1641/0006-3568 (2000)050[0035:nposgm]2.3.co;2

Ostrom, E., and M. Cox. 2010. Moving beyond panaceas: a multitiered diagnostic approach for social-ecological analysis. Environmental Conservation 37(4):451-463. https://doi.org/10.1017/ $\underline{\mathrm{S} 0376892910000834}$

Peterson, R., and D. L. Coppock. 2001. Economics and demographics constrain investment in Utah private grazing lands. Journal of Range Management 54(2):106-114. https://doi. org/10.2458/azu jrm v54i2 peterson

Primmer, E., R. Paloniemi, J. Similä, and D. N. Barton. 2013. Evolution in Finland's forest biodiversity conservation payments and the institutional constraints on establishing new policy. Society \& Natural Resources 26(10):1137-1154. https://doi. org/10.1080/08941920.2013.820814

Roche, L. M. 2016. Adaptive rangeland decision-making and coping with drought. Sustainability 8(12):1334. https://doi. org/10.3390/su8121334

Sala, O. E., L. Yahdjian, K. Havstad, and M. R. Aguiar. 2017. Rangeland ecosystem services: nature's supply and humans' demand. Pages 467-489 in D. D. Briske, editor. Rangeland systems: processes, management and challenges. Springer Series on Environmental Management, Cham, Switzerland. https://doi. org/10.1007/978-3-319-46709-2 14

Salzman, J., G. Bennett, N. Carroll, A. Goldstein, and M. Jenkins. 2018. The global status and trends of payments for ecosystem services. Nature Sustainability 1(3):136-144. https://doi. org/10.1038/s41893-018-0033-0

Sarwosri, A. W., J. Wegmann, and O. Mußhoff. 2018. Encouraging rainforest preservation by smallholders: an ex-ante policy evaluation. EFForTS Discussion Paper Series, No. 23, GOEDOC, Dokumenten- und Publikationsserver der GeorgAugustUniversität, Göttingen, Germany. [online] URL: http://nbnresolving.de/urn:nbn:de:gbv:7-webdoc-3984-3

Sayre, N. F. 2004. Viewpoint: the need for qualitative research to understand ranch management. Rangeland Ecology and Management 57(6):668-674. https://doi.org/10.2111/1551-5028 (2004)057[0668:VTNFQR]2.0.CO;2

Sloat, L. L., J. S. Gerber, L. H. Samberg, W. K. Smith, M. Herrero, L. G. Ferreira, C. M. Godde, and P. C. West. 2018. Increasing importance of precipitation variability on global livestock grazing lands. Nature Climate Change 8:214-218. https://doi.org/10.1038/ $\underline{\text { S41558-018-0081-5 }}$

Smith, P., O. Andrén, T. Karlsson, P. Perälä, K. Regina, M. Rounsevell, and B. V. Wesemael. 2005. Carbon sequestration potential in European croplands has been overestimated. Global Change Biology 11(12):2153-2163. https://doi.org/10.1111/ j.1365-2486.2005.01052.X

Soussana, J.-F., P. Loiseau, N. Vuichard, E. Ceschia, J. Balesdent, T. Chevallier, and D. Arrouays. 2004. Carbon cycling and sequestration opportunities in temperate grasslands. Soil Use and Management 20(2):219-230. https://doi.org/10.1111/j.1475-2743.2004. $\underline{\mathrm{tb} 00362 . \mathrm{x}}$
Spiegal, S., L. Huntsinger, P. Hopkinson, and J. W. Bartolome. 2016. Range ecosystems. Pages 835-864 in H. Mooney and E. Zavaleta, editors. Ecosystems of California. University of California Press, Berkeley, California, USA. https://doi. org/10.1525/9780520962170

Stone Barns Center for Food \& Agriculture (SBCFA) and Armonia LLC. 2017. Back to grass: the market potential for U.S. grassfed beef. SBCFA, Pocantico Hills, New York, USA. [online] URL: https://www.stonebarnscenter.org/wp-content/uploads/2017/10/ Grassfed Full v2.pdf

Teague, R., and M. Barnes. 2017. Grazing management that regenerates ecosystem function and grazingland livelihoods. African Journal of Range \& Forage Science 34(2):77-86. https:// doi.org/10.2989/10220119.2017.1334706

Thamo, T., and D. J. Pannell. 2016. Challenges in developing effective policy for soil carbon sequestration: perspectives on additionality, leakage, and permanence. Climate Policy 16 (8):973-992. https://doi-org.stanford.idm.oclc.org/10.1080/14693062.2015.1075372 https://doi.org/10.1080/14693062.2015.1075372

The Nature Conservancy (TNC). 2019.2019 Annual report. TNC, Arlington, Virginia, USA. [online] URL: https://www.nature.org/ en-us/about-us/who-we-are/accountability/annual-report/2019-annualreport

Tikkanen, J., R. Hokajärvi, T. Hujala, and M. Kurttila. 2017. Ex ante evaluation of a PES system: safeguarding recreational environments for nature-based tourism. Journal of Rural Studies 52:42-55. https://doi.org/10.1016/j.jrurstud.2017.03.011

Tipper, R., N. Coad, and J. Burnett. 2009. Is 'insetting' the new 'offsetting'? Econometrica Press. [online] URL: https:// ecometrica.com/assets/insetting offsetting technical.pdf

Toombs, T. J. H. Goldstein, C. Hanson, N. Robinson-Maness, and T. Frankhauser. 2011. Rangeland ecosystem services, risk management, and the ranch bottom line. Rangelands 33(5):1319. https://doi.org/10.2111/1551-501x-33.5.13

U.S. Department of Agriculture (USDA). 2020. FY 2020 budget summary. USDA, Washington, D.C., USA. [online] URL: https:// www.usda.gov/sites/default/files/documents/fy2020-budget-summary. pdf

Valoral Advisors. 2018. Impact investing in the global food and agricultural investment space. Valoral Advisors. [online] URL: https://www.valoral.com/wp-content/uploads/Valoral-Advisors-ImpactInvesting-November-2018.pdf

Vatn, A. 2010. An institutional analysis of payments for environmental services. Ecological Economics 69(6):1245-1252. https://doi.org/10.1016/j.ecolecon.2009.11.018

Vetter, S. 2005. Rangelands at equilibrium and non-equilibrium: recent developments in the debate. Journal of Arid Environments 62(2):321-341. https://doi.org/10.1016/j.jaridenv.2004.11.015

Westman, W. E. 1977. How much are nature's services worth? Science 197(4307):960-964. https://doi.org/10.1126/science.197.4307.960

Westoby, M., B. Walker, and I. Noy-Meir. 1989. Opportunistic management for rangelands not at equilibrium. Journal of Range Management 42(4):266-274. https://doi.org/10.2307/3899492 
Wilmer, H., and M. E. Fernández-Giménez. 2015. Rethinking rancher decision-making: a grounded theory of ranching approaches to drought and succession management. Rangeland Journal 37(5):517-528. https://doi.org/10.1071/RJ15017

World Resources Institute (WRI) and WBCSD. 2014. GHG protocol agricultural guidance: interpreting the corporate accounting and reporting standard for the agricultural sector. WRI, Washington, D.C., USA and WBCSD, Geneva, Switzerland. [online] URL: https://ghgprotocol.org/agriculture-guidance 


\begin{tabular}{|c|c|c|}
\hline $\begin{array}{l}\text { Corporations } \\
(22 \text { total) }\end{array}$ & $\begin{array}{l}\text { ADM } \\
\text { Bunge } \\
\text { Cargille } \\
\text { Corteva Agriscience } \\
\text { Danone North America } \\
\text { General Mills } \\
\text { Land O'Lakes } \\
\text { McDonald's } \\
\text { Nestle } \\
\text { Nutrien Ag Solutions } \\
\text { Syngenta }\end{array}$ & $\begin{array}{l}\text { Anuvia } \\
\text { Arva } \\
\text { Bayer } \\
\text { Farmers Business Network } \\
\text { Impact Ag Partners (IA) } \\
\text { K-Coe } \\
\text { Mars } \\
\text { Newtrient } \\
\text { Pivot Bio } \\
\text { Tatanka Resources } \\
\text { Tyson }\end{array}$ \\
\hline $\begin{array}{l}\text { NGOs / Foundations } \\
\text { (14 total) }\end{array}$ & $\begin{array}{l}\text { American Farmland Trust } \\
\text { Conservation Technology } \\
\text { Information Center } \\
\text { Farm Foundation } \\
\text { Field to Market } \\
\text { Low Carbon Prosperity Institute } \\
\text { Native Energy } \\
\text { NFWF }\end{array}$ & $\begin{array}{l}\text { Noble Research Institute } \\
\text { OpenTEAM } \\
\text { Sand County Foundation } \\
\text { Soil Health Institute } \\
\text { Soil Health Partnership } \\
\text { The Nature Conservancy } \\
\text { WWF }\end{array}$ \\
\hline $\begin{array}{l}\text { Associations } \\
\text { (9 total) }\end{array}$ & $\begin{array}{l}\text { Almond Board of California } \\
\text { American Soybean Association } \\
\text { American Sugarbeet Growers } \\
\text { Association } \\
\text { National Association of } \\
\text { Conservation Districts }\end{array}$ & $\begin{array}{l}\text { National Cattlemen's Beef } \\
\text { Association } \\
\text { National Corn Growers } \\
\text { Association } \\
\text { National Farmers Union } \\
\text { The Fertilizer Institute } \\
\text { TriSocieties }\end{array}$ \\
\hline $\begin{array}{l}\text { Other } \\
\text { (3 total) }\end{array}$ & $\begin{array}{l}\text { American Farm Bureau } \\
\text { Federation (Insurance company / } \\
\text { lobbyist) } \\
\text { Arizona State University } \\
\text { (University) }\end{array}$ & Trust in Food (Media) \\
\hline
\end{tabular}


Appendix 2. Interview protocol.

Semi-structured interviews were conducted by part or all of the research team by telephone, lasting 45 to 90 minutes. The following interview guides were used by the research team under IRB Protocol \#50991 (Exempt status).

\section{A: ESMC Member \& Expert Interviews}

1. Could you share a bit with us about your company and position, as a member of ESMC? How would you describe your company and what you do? Would you call your company a social or environmental-impact enterprise?

2. For how long has your company / team been interested in ag lands ecosystem services, and why? Where does that interest stem from? Are you involved in other initiatives on this topic besides ESMC?

3. Have you invested in ag lands ecosystem services in the past? How about rangelands specifically? Is your company or organization most interested in ranching or farmingbased outcomes, or are they equally important to you?

4. Why is the specific focus on rangelands and on soil/water of interest to your company or organization? Is your company or organization interested in the longer-term potential to expand the program to biodiversity outcomes?

Motivations \& Goals

5. What motivates you and your company to participate in ESMC? What are the principal reasons for your participation?

1. To manage greenhouse gas and water risk outcomes (e.g. utilities)

2. To meet environmental commitments stated in public or shareholder-facing documents

3. To meet conservation program goals (e.g. NGOs)

4. To meet present or expected regulatory obligations:

1. Sustainable Development Goals (SDGs)

2. SBTi (Science Based Target initiative) reporting

3. GHG Corporate Standard reporting (Scopes 1, 2 or 3)

4. Paris Climate Accord

5. Other

e. To create a robust marketplace for future ecosystem services

f. To produce credits for other companies to purchase?

g. To strengthen corporate brand associations with environmental sustainability

h. Other

6. Do you have concerns about your producers being able to access the ESMC market if you were not a member / is that a motivating reason for your participation? (e.g. right to 
operate, etc.)

7. Are you required to report on 1) carbon 2) GHGs 3) water quality and/or 4) water quantity metrics? What policy requires you to report on these things? For how long have you been reporting them?

8. On greenhouse gas emissions, when the market is open and credits/assets are being produced, is your company most interested in using these credits for scope 1 , scope 2 or scope 3 reporting?

a. On water, are you interested in Water Efficiency Credits or Water Quality Credits? Ag Water Quality Protection Certificates?

b. On carbon, are you interested in Carbon Inset Credits or Carbon Offset Credits?

c. Is there an opportunity to sell your insets as offsets?

9. How do you expect your reporting on carbon and water to change in the future? How might this impact your participation in ESMC's market?

10. Would your company purchase credits created by other producers or markets, such as Indigo Ag or Nori?

11. What about ESMC made you chose to participate in this initiative in particular?

1. Are ag companies inherently in a position to be producing these credits to increase sustainability/yield/PR opportunity or are they trying to offset Scope 3 emissions?

12. What aspects of the ESMC protocol are most important to you, and why?

a. Quantification, monitoring \& verification

b. Outcome-based compensation

c. Consortium approach with broad membership

d. Public relations and marketing impact of participation on corporate brand

e. Other

13. Will your company or organization publicize its participation in ESMC? Is communicating this work to the public an important part of your participation?

14. Would your company or organization brand or certify its products as being conservation/water/soil-friendly based on participation in the ESMC initiative?

15. What aspects of the program do you find most concerning or challenging, looking ahead? What is your greatest reservation about participating in a sector-wide carbon market?

16. In your mind, what are the greatest barriers to achieving a successful carbon offset market, and how would you suggest they be overcome? 
17. Are you primarily interested in outcomes in a certain geographic region? Is your company or organization's interest at the local, regional, national or global impact level when it comes to ESMC participation?

18. Would you be interested in applying your participation in this program internationally? What is the potential of ESMC to integrate across sectors, not just in terms of buyers but also sellers (e.g., energy, textiles, industry, non-ag etc.)

Other Questions

19. How important is it to you that the protocol for such a market be localized -- i.e. flexible to be locally-adjusted and fine-tuned to the specific context of a ranch?

20. Is ESMC interested in doing any joint lobbying? If so, what kind?

21. What is the future of ESMC in terms of connecting with international markets? Do you see it merging with the EU credit market or other international programs?

\section{B: California Cattle Rancher Interviews}

1. Operation overview

- Can you tell us/me about the type of operation that you run? (E.g. cow-calf, stocker, grass-finished, diversified, other)?

- Is ranching a family business for you? Have there been multiple generations involved in this ranch, or are you 1st generation? To what extent are you involved in ranch management decision-making, and who else participates in that process?

2. Defining Conservation \& Past Experience

- What does conservation on ranches mean to you?

- Have you done any conservation work on your ranch in the past? (For example: grazing management plan, water developments, cross fencing / riparian fencing, rangeland improvements, fire fuel load reduction, invasive species control, native plant restoration, oak planting)

- How has this work impacted your rangeland?

- What is your main goal for doing the conservation work you do?

3. Government Funded Programs

Have you participated in conservation-focused programs through the USDA or another government agency? For example, cost-share programs or Farm Bill conservation incentive programs via NRCS?

- (If they say "yes"): Which program? EQIP (e.g. for riparian fencing or off-stream water systems like solar pumps)? CRP/GRP (conservation/grassland reserve program)? Are you part of the Williamson Act? Other?

- For how long have you been a part of this program?

- Why do you participate?

- How did you learn about it? 
- What are some of the main challenges that you have faced while participating in the program? Could you provide some examples of these challenges?

- What are some of the benefits you've seen through being a part of this program?

- How time consuming is it to participate?

- Do you find participation in this program to be a burden on your workload?

- Do you participate in this program alone or in collaboration with other ranchers?

- Has being a part of this program increased your revenue?

- (If "yes") If you could put a percentage in that increase, what would it roughly be?

- If you could make changes to this program, what would you like to change?

- Do you think that the program achieves its intended goal?

- (If they say "no"):

- Why not? Were you aware of it?

- Would you consider participating in the future?

- What would you look for in a program like this for you to be able to participate? [For research team: try to identify any economic, social, or environmental factors that would most strongly incentivize participation.]

4. Price Premiums \& Certification Schemes

A second category of payments to ranchers for conservation is certain price premiums for niche market products, as in through farmers markets or branded corporate programs. Have you thought about doing any sustainability certifications or other branded programs that recognize certain sustainable or "conservation" focused approaches? Are you marketing any conservation values in your beef? E.g. Grassfed, organic, wildlife-friendly (e.g. Audubon's new bird-friendly certification, predator-friendly?

If "yes":

- For how long have you been a part of this program?

- How did you learn about it?

- Why do you participate?

- What are some of the main challenges that you have faced?

- What are some of the benefits you've seen through being a part of this program?

- How time consuming is it?

- Do you find this to be a burden on your workload?

- Has being a part of this program increased your revenue?

- (If "yes") If you could put a percentage in that increase, what would it roughly be?

- If you could make changes to this program, what would you like to change?

- Have you heard about regenerative beef, and what does that mean to you? Do you think you could earn more selling "regenerative" beef? 
- Have you sold your products through farmers markets or director-to-consumer? (Why / Why not?)

If "no":

Why not?

- Would you consider participating in the future?

- What would you look for in a program like this for you to be able to participate? (i.e. economic, social, or environmental factors that would most strongly incentivize participation)

5. Payments for Ecosystem Services (Voluntary \& Regulatory markets) Are you familiar with formal Payment for Ecosystem Services, programs like the Chicago Climate Exchange that paid ranchers for soil carbon? Have you ever thought about participating in this kind of market?

If "yes":

- For how long have you been a part of this program?

- How did you learn about it?

- Why did / do you participate?

- What are some of the main challenges that you have faced?

- What are some of the benefits you've seen through being a part of this program?

- How time consuming is it?

- Do you find this to be a burden on your workload?

- Has being a part of this program increased your revenue?

- (If "yes") If you could put a percentage in that increase, what would it roughly be?

- If you could make changes to this program, what would you like to change?

If "no":

Why not?

- Would you consider participating in the future?

- What would you look for in a program like this for you to be able to participate? (i.e. economic, social, or environmental factors that would most strongly incentivize participation)

6. New Carbon \& Water Market: ESMC

There is a new pilot carbon and water credits market in development by a group of corporations and nonprofits that have come together to launch a soil carbon and water market geared at ranchers and farmers. It will be launched in 2022, and they're testing it now on ranchers covering about 70,000 acres in Texas and Oklahoma.

- Would you be interested in this sort of program that would pay per amount of carbon sequestered or water saved?

- What concerns would you have about such a program? 
- Would monitoring be an issue for you? Does it matter to you who does the monitoring? (NGO vs. corporation vs. government vs. rancher) What type of monitoring would be ok with you, and what types of monitoring might you have issue with?

- Outcome-based compensation?

- How important to you is who runs the market (non-profit or corporation)?

- Other challenges as factors influencing participation?

- Would you be interested in reviewing further details about this program when they are available?

- What is most important to you regarding your participation in such a program? What would it take for you to participate?

- Would you have a preference for whether you were paid for your carbon or water asset by a non-profit organization vs. a corporation/LLC?

- How much would you need to be paid (per acre) for your participation in a PES program to be worthwhile even considering? Within what time period would you need to be compensated to make it worth your time?

- Some of these programs may require that you provide current and historic management plans and stocking rates, potentially back three years. Would you be able and willing to do that?

- Would you be willing and able to supply irrigation records, including type of irrigation system and diversion records, times of irrigation and amounts?

- Would you be comfortable with baseline and ongoing soil sampling on your property, on an annual basis? (Using a new technology called Quick Carbon, which measures down to $30 \mathrm{~cm}$.)

- Some producers in the Great Plains are starting to participate in a pilot program with ESMC where these methods are being tested on their properties (without compensation yet), in the hopes that when the market opens in 2022, that these producers will be the first to be able to sell carbon assets on the carbon market. Would you be interesting in participating in such a pilot, if it were to come to California?

- There is a possibility in some of these markets that the payback time would be 5 years, for there to be proven change in soil carbon. Would you be willing to participate in a program with that 5-year timeline to payment?

- If you'd be interested in participating in a payment for ecosystem services program, is your motivation for doing it the income from your participation, the potential opportunity to improve yields or your overall operation, or to steward the land?

- How important is it to you that the protocol or rules for participation in such a market be localized -- i.e. flexible to be locally-adjusted and fine tuned to the specific context of a ranch? 
7. Land conservation: A final category of payments to ranchers for conservation is land conservation opportunities often coordinated by NGOs, like conservation easements. Is this something you have considered participating in before? Why or why not?

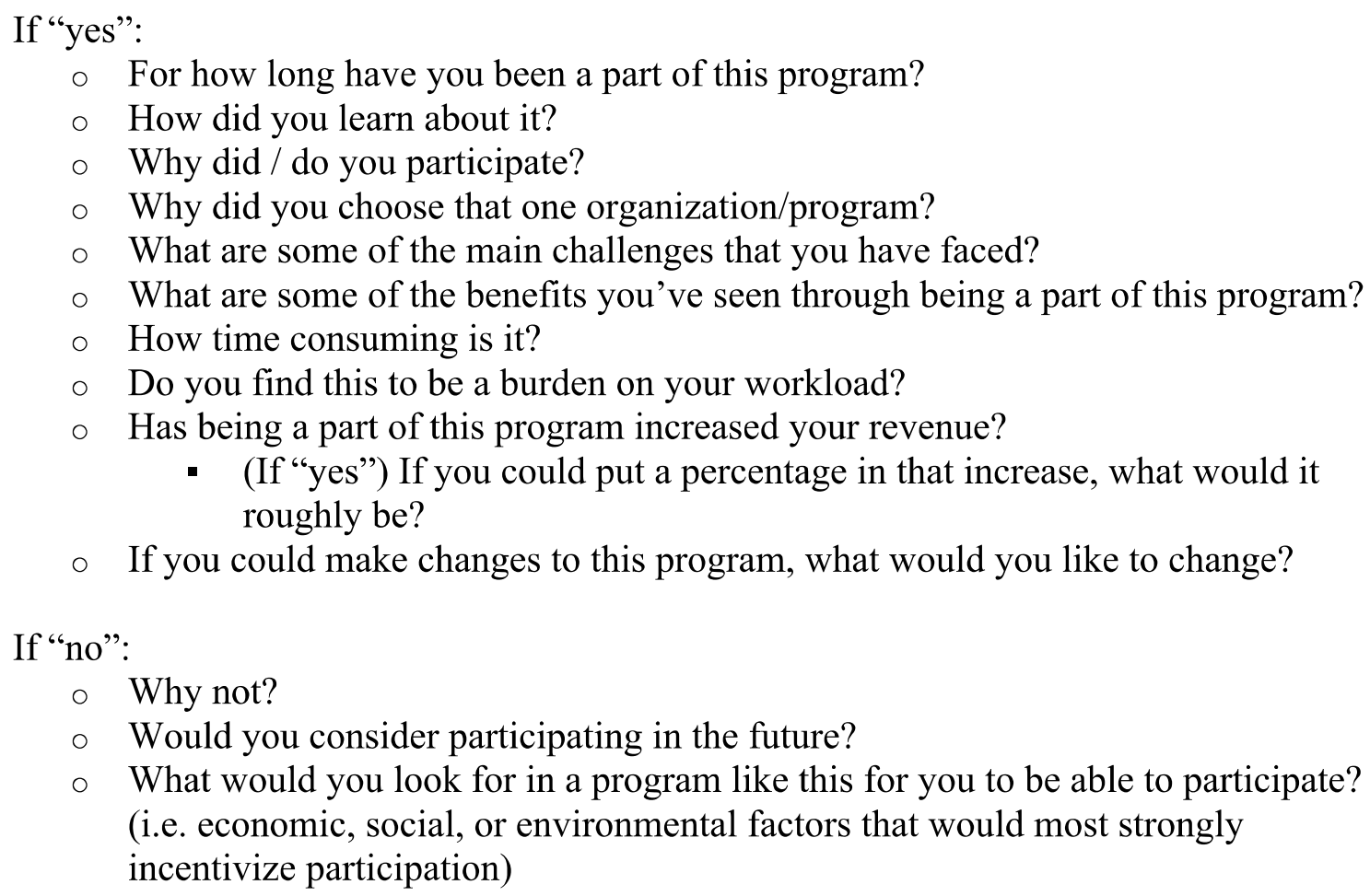

Final survey questions

8. How long have you been ranching for?

9. What age range would you describe yourself in?

$$
\begin{array}{ll}
\circ & 20-40 \\
\circ & 40-65 \\
\circ & \text { over } 65 \text { years }
\end{array}
$$

10. Similarly, what range of livestock numbers would you put yourself in:

$$
\begin{array}{ll}
\circ & \text { Fewer than } 50 \text { cows } \\
\circ & 50-100 \\
\circ & 100-500 \\
\circ & 500+?
\end{array}
$$

11. Is ranching your principal occupation or part-time, etc.? 


\begin{tabular}{lll}
\hline Statistic & Description & 46 \\
\hline Years & Average years ranching (median) & 1 \\
Age & Number of ranchers interviewed aged 20-40 years & 5 \\
& Number of ranchers interviewed aged 41-64 years & 8 \\
& Number of ranchers interviewed aged 65+years & 2 \\
Livestock & Number of ranchers interviewed with under 50 head of cattle & 1 \\
& Number of ranchers interviewed with 50-100 head of cattle & 6 \\
& Number of ranchers interviewed with 100-500 head of cattle & 6 \\
& Number of ranchers interviewed with 500+ head of cattle & 4 \\
& Number of ranchers interviewed with unknown \# cattle & 1 \\
Ranching Occupation & Number of ranchers interviewed who ranched full-time & 8 \\
\cline { 2 - 3 } & Number of ranchers interviewed who ranched part-time & 6
\end{tabular}


Appendix 4. Factors motivating members to participate in ESMC, with interview quotes ( $n=10$; $\mathrm{C}=$ consortium member).

Motivating Factor Description \& Relevant Interview Excerpts

(Mention Frequency)

Influencing producers (9) These responses spoke to the challenge of influencing agricultural producers to change practices and emphasized that financing through PES markets is needed to scale sustainable practices. Some interviewees spoke of their interest in augmenting producers' earnings as the main motivator for participating in ESMC.

"It seems to be that if you want to get adoption of these things and you want farmers that join, they may do it because they are concerned about the environment, the long term health, passing the farm on to the next generation thing - all are very important. But if we can financially incentivize the adoption of some of these things, I think we're going to have a bigger impact on long term benefits than if it remains an externality that is never monetized." (C6)

"I can see how the economic compensation piece must play a huge role in changing hearts and minds of farmers." (C3)

"You've got corporations that have got a great form of offset that's tangible and I think it draws really good behavior." (C17)

Corporate commitments (9)

These responses spoke to the utility of ESMC in helping members to meet their corporate commitments (e.g., ESG commitments, sustainable sourcing, shareholder activism, shifting away from Corporate Social Responsibility to new approaches).

"A large agricultural company makes a public claim around reducing its greenhouse gas emissions and then uses the ESMC to streamline and facilitate management of its own supply chain to meet its emissions reductions targets. That's what ESMC refers to as insetting." (C13)

"Carbon neutrality commitments by 2050. Science Based Target initiative commitments: $30 \%$ greenhouse gas reduction by 2030 . Of those commitments, we look at our entire supply chain going down to the farm, called the Scope 3 commitments of greenhouse gas emissions. So, pretty hefty commitments...We're not looking to offset, we're looking to inset. We're trying to achieve our goals by getting reductions out of what's in our scope of work, our supply chain." (C9)

Collaboration (9) These responses had to do with the utility of the consortium approach in providing a single, consistent effort that would bolster public confidence, particularly because of the alignment across the 
agricultural industry on methodologies and reporting.

"I think making sure that the Science Based Target Initiative accepts inset credits is important ... Getting groups like the World Resources Institute and GHG Protocol on board, making sure that they all recognize these reductions is as legitimate will be an important challenge...getting industry-wide movement is really, really important for us." (C12)

"Why did we join this group? Well, we see it as probably one of the most collaborative groups out there... members come from corporations or universities, federal governments, state governments, nonprofits, and so we are nationally trying to be collaborative and not exclusive." (C8)

"I think like there is an absence of a regulatory body around this... I don't think that ESMC should be that regulatory body, but I do think everybody who's interested in this has a shared interest in working together to develop as good a protocol as possible." (C7)

"A lot of what we do is trying to engage with the rest of the food and ag industry and try to make sure that we're bringing them along with us on this stuff." (C3)

Business strategy (8) These responses spoke to the role of ESMC in helping companies to be competitive, either by building long-term supply chain resilience or as part of companies' publicity strategy.

"I think there's this need to be collaborative and to build up these really important environmental efforts in a way that engages across the supply and involves multiple stakeholders. And that is huge reputationally for all the companies that are involved... [Company name] sees this as a differentiator and a competitive edge..." (C10)

"We think it's important for the public and for our members to know about .... we're proud of this, of the efforts that we joined." (C6)

"Consumers and consumers are caring more than ever about you know, making sure that their food is grown in a way that's good for the planet and good for people." (C3)

"It is an important part of the story and we do want to be able to tell the important messages that we're working with North American farmers and ranchers to care for the environment and ensure our products are sustainably sourced." (C12)

Establishing scientific These responses spoke to the member wanting to contribute to creating the quantification, verification and reporting process. Responses included the need to merge this effort with other protocols (e.g. the 
Science Based Targets Initiative and Greenhouse Gas Protocol).

"We want to try and help influence and having input into the research and the monetization and natural capital in the U S." (C17)

"Like in any successful ecosystem service marketplace, you need a really solid and scientifically based way to measure the carbon or whatever ecosystem service you're providing." (C7)

"The quantification and monitoring is probably the most important." (C12)

"I actually have confidence that the private market will evolve faster than any government driven protocol." (C17)

"You need to tailor these sorts of models and calibrate them for each type of production system in each region, the soil type, there's a lot of uncertainty when you move to a different type of system. So yeah, I think there's a lot of model calibration to do, but also just understanding what the potential is for carbon sequestration." (C3) 


\begin{tabular}{|c|c|}
\hline Theme & Relevant Interview Excerpts \\
\hline \multicolumn{2}{|c|}{ ESMC Member / Expert Interviews ( $\mathrm{C}=$ consortium member $)$} \\
\hline $\begin{array}{l}\text { Unknown demand for } \\
\text { offsets }\end{array}$ & $\begin{array}{l}\text { "The most important piece is: What's the demand? We can set } \\
\text { up protocols, we can find farmers, we can get pilots done, but } \\
\text { who's going to ultimately buy from this market?" (C5) } \\
\text { "I don't really know what the demand is out there or the } \\
\text { appetite from other companies for buying these things ... I } \\
\text { don't really know a lot about the status of that demand side." } \\
\text { (C3) }\end{array}$ \\
\hline $\begin{array}{l}\text { Importance of measurements } \\
\text { and monitoring }\end{array}$ & $\begin{array}{l}\text { "We've been trying to really hold the line on the outcomes } \\
\text { piece ... We don't want regenerative ag just to become another } \\
\text { sort of checklist type thing. We're really pushing, stressing that } \\
\text { the need for measurement." (C3) }\end{array}$ \\
\hline $\begin{array}{l}\text { Benefits and challenges of } \\
\text { the collaborative approach }\end{array}$ & $\begin{array}{l}\text { "The most important piece to us is the multi-stakeholder } \\
\text { consortium aspect. That's the one thing that ESMC seems to be } \\
\text { in the best position to do, which is to pull together a really } \\
\text { broad group of companies, of other partners, of funding sources } \\
\text { and to use those companies and other partners' relationships to } \\
\text { actually have a pretty broad engagement of producers. So we're } \\
\text { much more interested in trying to support and be part of a } \\
\text { multi-party effort like this rather than a single company trying } \\
\text { to develop and design a carbon payment system for its own } \\
\text { producers and then sell them to others" (C13) } \\
\text { "There's this weird tension ... Where [companies say] 'We want } \\
\text { to be collaborative. We want to be part of this important step } \\
\text { for our farmers and our members.' But at the same time... } \\
\text { 'We've got to stop people coming in trying to steal market } \\
\text { share and promise things that they can't deliver on.' [We are] } \\
\text { going to be watching and making sure that the thing is actually } \\
\text { feasible and at the same time, maybe like any company } \\
\text { involved, looking at other opportunities." (C10) }\end{array}$ \\
\hline
\end{tabular}




\begin{tabular}{|c|c|}
\hline $\begin{array}{l}\text { Insetting \& Scope } 3 \\
\text { emissions reductions }\end{array}$ & $\begin{array}{l}\text { "Scope } 3 \text { is... where the action is for us because that's the } \\
\text { supply chain more broadly as opposed to the facilities or the } \\
\text { plants themselves...that's where we're really focusing our } \\
\text { energy." (C3) } \\
\text { "Our hopes for the ecosystem services market is that carbon } \\
\text { insetting can be more efficient, equally as credible, but doesn't } \\
\text { have to have all of the assurances that a traded commodity has } \\
\text { to have." (C12) } \\
\text { "Scope three requires the buyers of the credits to be engaged in } \\
\text { the intervention. It is a company that is looking at their own } \\
\text { supply chain, in this case, agriculture... Right now, Scope } 3 \text { is } \\
85 \text { to } 90 \% \text { of the demand. Whether that will change in the } \\
\text { future I think remains to be seen." (C16) } \\
\text { "The Science Based Targets Scope } 3 \text { emissions reduction goal } \\
\text {... is a big motivator for them to try to reduce their greenhouse } \\
\text { gas footprint ... all these companies, we have emissions } \\
\text { reduction goals that we have to meet for our public } \\
\text { commitments." (C3) }\end{array}$ \\
\hline $\begin{array}{l}\text { Need for risk mitigation and } \\
\text { financial incentives }\end{array}$ & $\begin{array}{l}\text { "People in agriculture don't just make huge dramatic changes } \\
\text { impulsively, and things change with time. There is a lot of } \\
\text { money and stuff at stake out there for them. Every year. And } \\
\text { they already have so many unknowns, the chief one being } \\
\text { money. And if they had practices that have worked for them in } \\
\text { the past, maybe given a livelihood, it's difficult for them to } \\
\text { break away from what they're doing." (C6) } \\
\text { "This could be globally very powerful if we can monetize this } \\
\text { because all of a sudden it takes the financial pressure off a } \\
\text { farmer." (C17) }\end{array}$ \\
\hline $\begin{array}{l}\text { Challenge of scaling the } \\
\text { market }\end{array}$ & $\begin{array}{l}\text { "[The greatest challenge is the] ability to measure [soil carbon] } \\
\text { changes over huge swaths of land very cheaply." (C3) } \\
\text { "One of the biggest challenges is maintaining rigor while } \\
\text { achieving scale and cost. We can very accurately measure } \\
\text { everything that we are interested in. You can't do that at scale } \\
\text { and cost effectively. Right now, [we]'re trying to figure out } \\
\text { what is the best way to achieve scale, cost effectively while } \\
\text { maintaining rigor. We have to do all of this in a transparent } \\
\text { fashion and ensure that we're meeting all of the existing } \\
\text { standards." (C16) }\end{array}$ \\
\hline
\end{tabular}




\begin{tabular}{|l|l|}
\hline Rancher Interviews (R= participant rancher) \\
\hline $\begin{array}{l}\text { Limitations of existing } \\
\text { conservation PES programs }\end{array}$ & $\begin{array}{l}\text { "There's pros and cons to it as well. If we need to do it, we } \\
\text { need to do it. But now you also have a partner in your business } \\
\text { as well as far as if you want to make any big changes." (R15) } \\
\text { "The one drawback [of certifications] for me is I'm a small } \\
\text { enough producer ... if I can't offer them a full truckload, either } \\
\text { they're going to discount me the difference in trucking or } \\
\text { they're just not even gonna look at my calves. And so around } \\
\text { here, I don't think anybody would be looking for grassfed cattle } \\
\text { to buy and turn out in the California summer. They'd have to go } \\
\text { to another state that has summer grass. So the logistics of that } \\
\text { with my size don't work ... I think that premiums just doesn't } \\
\text { work for my herd size." (R8) }\end{array}$ \\
\hline $\begin{array}{l}\text { Ranchers would require } \\
\text { rigorous science, high } \\
\text { enough payment, and risk } \\
\text { mitigation to participate in } \\
\text { carbon markets }\end{array}$ & $\begin{array}{l}\text { "I didn't think the science was there yet." (R1) } \\
\text { "\$15-20 per metric ton of carbon is never going to be enough } \\
\text { money ... if we really want to see some incentive programs for } \\
\text { ranchers that get to the next step, it needs to be more like \$70, } \\
\$ 80 \text { a metric ton." (R15) }\end{array}$ \\
\hline $\begin{array}{l}\text { Comfort sharing records to } \\
\text { participate in ESMC }\end{array}$ & $\begin{array}{l}\text { "I'd certainly be comfortable sharing my stocking rates-I } \\
\text { already share it with the Forest Service because our ranch is } \\
\text { intermingled with National Forest... Historically I would have } \\
\text { said no. But now with SGMA, we're all gonna have to share } \\
\text { records." (R3) }\end{array}$ \\
\hline
\end{tabular}

